National Water Availability and Use Program

Compilation of Regional Ground-Water Divides for Principal Aquifers Corresponding to the Great Lakes Basin, United States

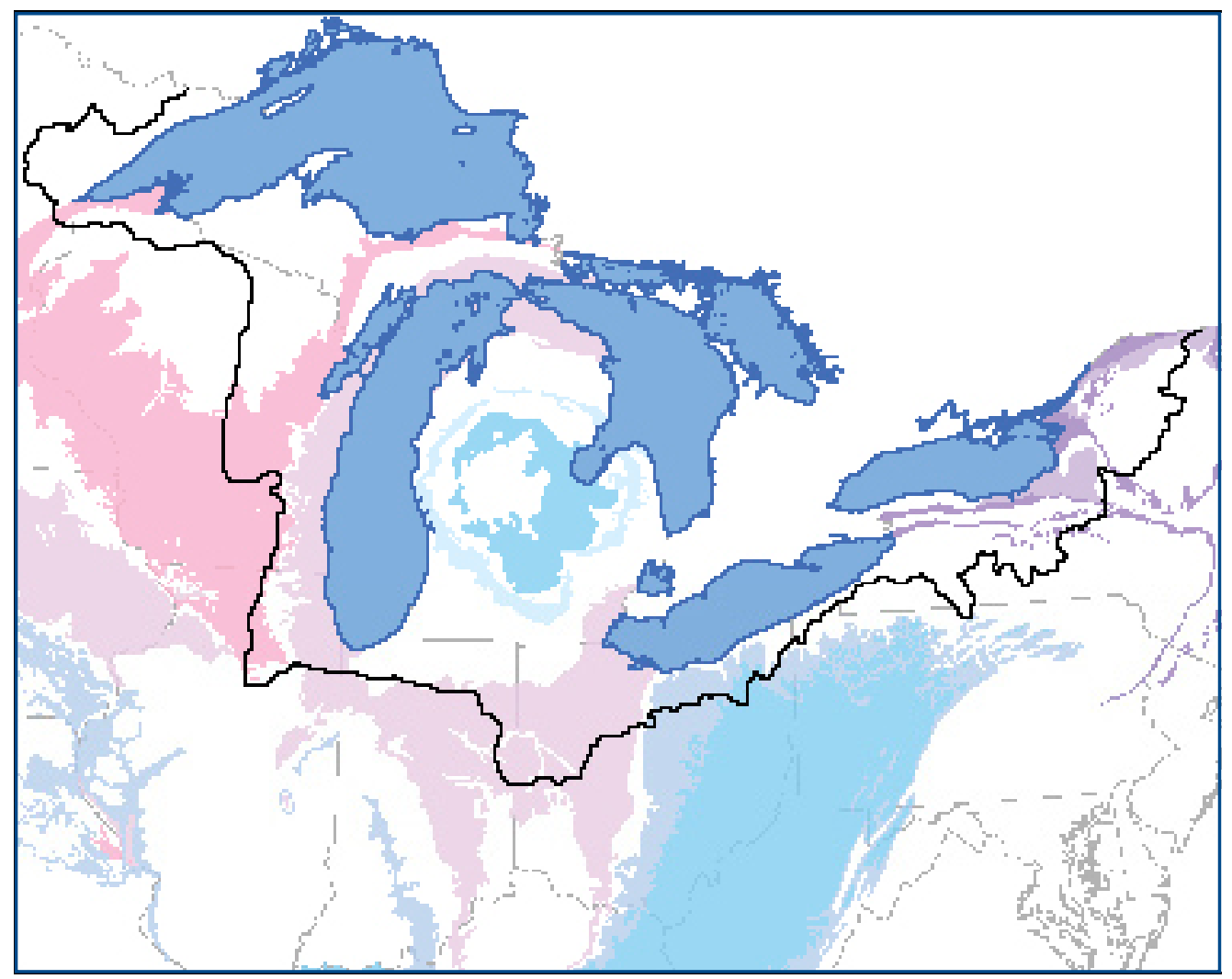

Scientific Investigations Report 2006-5102 


\section{Compilation of Regional Ground-Water Divides for Principal Aquifers Corresponding to the Great Lakes Basin, United States}

By R.A. Sheets and L.A. Simonson

National Water Availability and Use Program

Scientific Investigations Report 2006-5102 


\section{U.S. Department of the Interior \\ P. Lynn Scarlett, Acting Secretary}

\section{U.S. Geological Survey \\ P. Patrick Leahy, Acting Director}

\section{U.S. Geological Survey, Reston, Virginia: 2006}

For product and ordering information:

World Wide Web: http://www.usgs.gov/pubprod

Telephone: 1-888-ASK-USGS

For more information on the USGS - the Federal source for science about the Earth, its natural and living resources, natural hazards, and the environment:

World Wide Web: http://www.usgs.gov

Telephone: 1-888-ASK-USGS

Any use of trade, product, or firm names in this publication is for descriptive purposes only and does not imply endorsement by the U.S. Government.

Although this report is in the public domain, permission must be secured from the individual copyright owners to reproduce any copyrighted materials contained within this report.

Suggested citation:

Sheets, R.A. and Simonson, L.A., 2006, Compilation of regional ground-water divides for principal aquifers corresponding to the Great Lakes Basin, United States: U.S. Geological Survey Scientific Investigations Report 2006-5102, $23 \mathrm{p}$ 


\section{Contents}

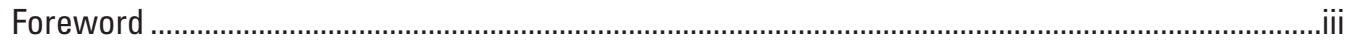

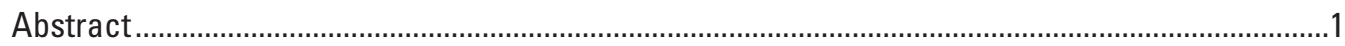

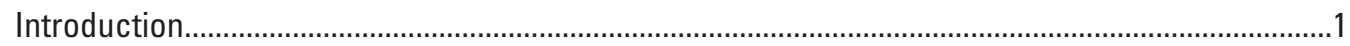

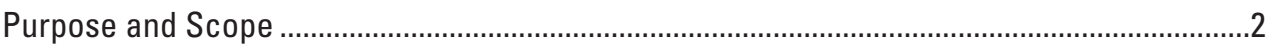

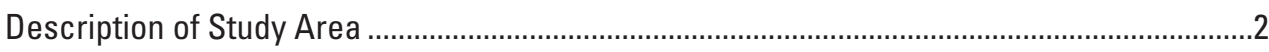

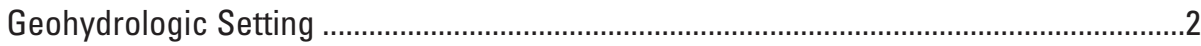

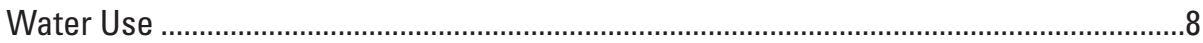

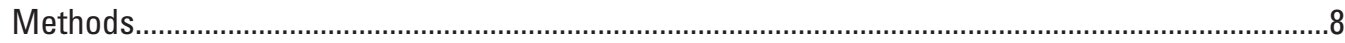

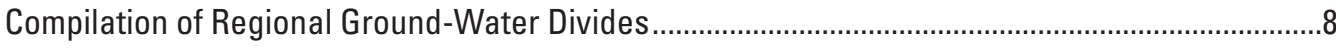

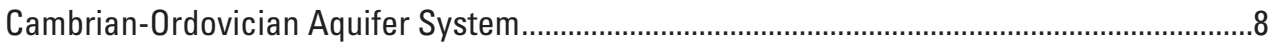

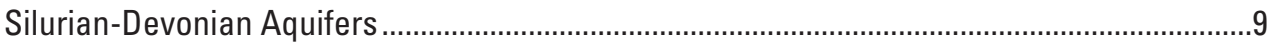

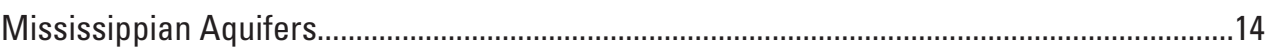

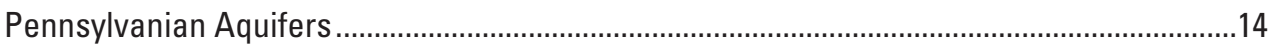

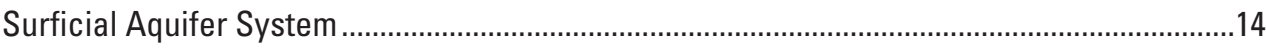

Composite Regional Ground-Water Divides for Consolidated-Rock Aquifers ................................17

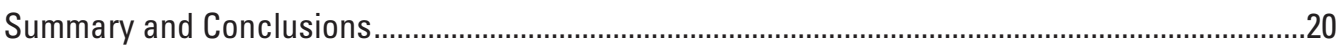

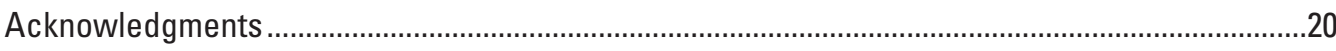

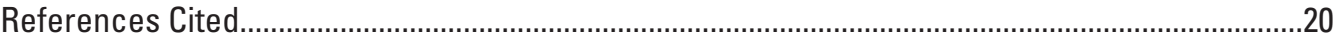

Box 1. Factors Affecting Position of Regional Ground-Water Divides.............................................12

\section{Figures}

1-3. Maps showing -

1. Great Lakes surface-water basin ...................................................................................

2. Bedrock geology of the Great Lakes region in the United States, including major structural features .........................................................................................

3. Principal bedrock aquifers in the Great Lakes region; surficial aquifer system primarily overlies area north of the limit of Wisconsinan glaciation

4. Generalized hydrostratigraphic section of the Great Lakes Basin, United States

5-9. Maps showing location of-

5. Measured or inferred ground-water divides in the Cambrian-Ordovician aquifer system in the Great Lakes region at different times from predevelopment through 2000

6. Simulated ground-water divides in the Cambrian-Ordovician aquifer system in the Great Lakes region at different times from predevelopment through 2000

7. Simulated and measured ground-water divides in the Silurian-Devonian aquifer in the Great Lakes region at different times from predevelopment through 1990

8. Measured ground-water divides in the Mississipian and Pennsylvanian aquifers in the Great Lakes region

9. Regional ground-water divides of the surficial aquifer system in the Great Lakes region from different time periods from 1970 through 2001 
10. Composite ground-water divides in the principal consolidated-rock aquifers in the Great Lakes region, United States.

\section{Table}

1. Generalized stratigraphic and hydrostratigraphic section of the

Great Lakes Basin in the United States

\section{Conversion Factors, Datums, and Abbreviations}

\begin{tabular}{lcl}
\hline \multicolumn{1}{c}{ Multiply } & By & \multicolumn{1}{c}{ To obtain } \\
\hline & Length & \\
\hline foot $(\mathrm{ft})$ & 0.3048 & meter $(\mathrm{m})$ \\
mile $(\mathrm{mi})$ & 1.609 & kilometer $(\mathrm{km})$ \\
\hline & Area & \\
\hline square mile $\left(\mathrm{mi}^{2}\right)$ & 2.590 & square kilometer $\left(\mathrm{km}^{2}\right)$ \\
\hline & Volume & \\
\hline cubic mile $\left(\mathrm{mi}^{3}\right)$ & 4.168 & cubic kilometer $\left(\mathrm{km}^{3}\right)$ \\
\hline & Rate & \\
\hline million gallons per day & 0.04381 & cubic meter per second $\left(\mathrm{m}^{3} / \mathrm{s}\right)$ \\
(Mgal/d) & & millimeter per year $(\mathrm{mm} / \mathrm{yr})$ \\
inch per year (in/yr) & 25.4 &
\end{tabular}

Vertical coordinate information is referenced to the North American Vertical Datum of 1988 (NAVD 88).

Horizontal coordinate information is referenced to the North American Datum of 1983 (NAD 83) and the Albers projection.

Altitude or elevation, as used in this report, refers to distance above the vertical datum.

Other abbreviations used in this report:

IDNR Indiana Department of Natural Resources

RASA Regional Aquifer Systems Analysis

USGS U.S. Geological Survey 


\title{
Compilation of Regional Ground-Water Divides for Principal Aquifers Corresponding to the Great Lakes Basin
}

\author{
By R.A. Sheets and L.A. Simonson
}

\section{Abstract}

A compilation of regional ground-water divides for the five principal aquifers corresponding to the Great Lakes Basin within the United States is presented. The principal aquifers (or aquifer systems) are the Cambrian-Ordovician aquifer system, Silurian-Devonian aquifers, Mississippian aquifers, Pennsylvanian aquifers, and the surficial aquifer system. The regional ground-water divides mark the boundary between ground-water flow that discharges to the Great Lakes or their tributaries and ground-water flow that discharges to other major surface-water bodies, such as the Mississippi River. Multicounty to multistate (regional) hydrologic studies of the five principal aquifers were reviewed to determine whether adequate data, such as potentiometric surfaces or groundwater divides, were available from which ground-water flow directions or ground-water-divide locations could be derived. Examination of regional studies indicate that the regional ground-water divides for the Cambrian-Ordovician aquifer system and Silurian-Devonian aquifers have changed over time and differ from the surface-water divides in some areas. These differences can be attributed to either pumping or natural processes. The limited information on the shallow Mississippian and Pennsylvanian bedrock aquifers indicate that these aquifers and the surficial aquifer system act as one hydrostratigraphic unit and that downdip flow is insignificant. Generally, in the Mississippian and Pennsylvanian aquifers, regional ground-water divides are similar to regional surface-water divides. Previous studies of the regional ground-water divide of the surficial aquifer system depict the regional groundwater divide as generally following the regional surface-water divide.

Because studies commonly focus on areas where groundwater use from an aquifer system is concentrated, the regional ground-water divides are not known in large, unstudied parts of some of these aquifer systems. A composite ground-water divide for the region was generated and is estimated to generally follow the surface-water divide, except in areas where anthropogenic or natural factors affect its position.

\section{Introduction}

In 2005, the U.S. Geological Survey (USGS) began the National Assessment of Water Availability and Use at the request of Congress (U.S. Geological Survey, 2002); a pilot phase immediately began in the Great Lakes region (Grannemann, 2005). The goal of the program is to provide citizens, communities, and natural-resource managers with

- a clearer knowledge of the status of the Nation's water resources (how much water we have now),

- trends over recent decades in water availability and use, and

- an improved ability to forecast the availability of water for future economic and ecological uses (U.S. Geological Survey, 2005b).

The Great Lakes surface-water basin is delineated by surface topography. The basin divide is defined as the line separating streams that ultimately drain into the Great Lakes from those draining to other major rivers or their tributaries (for example, the Mississippi River) (fig. 1). For the purposes of this report, the "Great Lakes Basin" is defined as the Great Lakes surface-water basin, excluding the St. Lawrence River Basin. The Great Lakes ground-water basin for a particular aquifer or aquifer system is delineated by that aquifer system's regional ground-water divide, which marks the separation of ground-water flow toward the Great Lakes from groundwater flow toward other major river basins. There are multiple principal aquifers or aquifer systems within the Great Lakes ground-water basin, each of which may discharge ground water directly to the Great Lakes or to tributaries to the Great Lakes. Principal aquifers are defined herein as rock units that will yield usable quantities of water to wells (Miller, 1999;

U.S. Geological Survey, 2003).

There has been no systematic, basinwide mapping of the water-table or potentiometric surfaces of these aquifers or aquifer systems - collectively referred to as "principal aquifers" hereafter- to define the regional ground-water divides between the Great Lakes and other major points of ground-water discharge. To date, only regional or subregional studies have been done on individual principal aquifers in the 
Great Lakes ground-water basin. Regional ground-water flow divides need to be better defined to more clearly delineate the parts of aquifers that can potentially affect the water quality of the Great Lakes. Illustrating areas where the surface- and ground-water divides are coincident or dissimilar will help regional water managers better understand diversion and water-availability issues in the region. Indicating where these data are lacking will provide water managers with information on areas to focus future investigations of ground-water resources.

\section{Purpose and Scope}

The purpose of this report is to provide a compilation of previous regional-scale (multicounty to multistate) investigations that help define the location of the regional ground-water divides for the principal aquifers that correspond to the Great Lakes Basin (in the United States). This report presents a series of maps indicating the position of the regional groundwater divides for principal aquifers based on these previous investigations. The previous investigations examined for this report were limited to state- and Federal-agency investigations and selected theses and dissertations that were regional in scope. This report also describes some of the factors that may affect the position of ground-water divides.

\section{Description of Study Area}

The Great Lakes Basin, including the surface area of the Great Lakes, comprises approximately $325,000 \mathrm{mi}^{2}$ in the Upper Midwestern United States and southeastern Canada (fig. 1); approximately $118,000 \mathrm{mi}^{2}$ of the basin land area lies within the United States. Overall, land use in the United States part of the Great Lakes Basin is approximately 50 percent forest and 40 percent agricultural land; however, the Lake Erie Basin is about 60 percent agricultural land, whereas the Lake Superior Basin is approximately 80 percent forest (Government of Canada and U.S. Environmental Protection Agency, 1995).

The climate of the Great Lakes Basin is controlled by movement of air masses from the Arctic zone and from the Gulf of Mexico and is moderated by the size and position of the Great Lakes within a large continental land mass. Spring and autumn in the Great Lakes Basin are characterized by variable weather corresponding to alternating air masses originating in the Arctic zone and the Gulf of Mexico. In winter, cold arctic air moves across the basin and absorbs moisture from the comparatively warmer Great Lakes; cooling and condensation as the air masses reach land creates heavy snowfalls on the leeward side of the Great Lakes. In summer, most of the Great Lakes Basin is dominated by warm, humid air from the Gulf of Mexico, and only the most northern part of the basin receives cooler and drier air from the Canadian northwest (Government of Canada and U.S. Environmental Protection Agency, 1995).
The population within the Great Lakes Basin (United States) has been estimated at about 25 million people, about 80 percent of which live in either the Lake Michigan Basin or the Lake Erie Basin (Government of Canada and U.S. Environmental Protection Agency, 1995).

The physiography of the Great Lakes Basin is, in large part, the result of a series of continental glaciers that scoured the area, the latest of which is the Laurentide Ice Sheet of the Wisconsin-stage glaciation during the Pleistocene Epoch. Most of the Great Lakes Basin is covered by glacial landforms such as moraines and till plains (Fenneman and Johnson, 1946). The consolidated rocks that underlie the glacial and alluvial terrain have a subdued subsurface topography because of glacial scouring. Land-surface altitudes range from over $1,600 \mathrm{ft}$ in northeastern Wisconsin and northern New York to less than $300 \mathrm{ft}$ near the Lake Ontario outlet to the St. Lawrence River. The maximum depth in the Great Lakes is in Lake Superior, at more than 1,300 ft.

\section{Geohydrologic Setting}

A series of large-scale structural basins and arches control the position and extent of bedrock units in the north-central part of the United States. Among these are the Michigan Basin, Illinois Basin, Appalachian Basin, the Wisconsin Arch, the Kankakee Arch, the Cincinnati Arch, and the Findlay Arch (Cohee, 1962; fig. 2). Bedrock in this area ranges from Precambrian to Jurassic in age (table 1; fig. 2). Precambrian units consist of crystalline rocks and metamorphosed sedimentary rocks. Paleozoic and Mesozoic rocks are sedimentary. Bedrock units dip away from the crests of the arches and generally thicken into adjacent basins (fig. 2).

Several principal aquifers correspond to the Great Lakes Basin: Cambrian-Ordovician aquifer system, Silurian-Devonian aquifers, Mississippian aquifers, Pennsylvanian aquifers, and aquifers of alluvial and glacial origin (hereafter termed the "surficial aquifer system") (fig. 3, table 1; U.S. Geological Survey, 2003). The surficial aquifer system overlies much of the area covered by Wisconsinan glaciation (fig. 3). Several less regionally extensive aquifers or aquifer systems are included in this nomenclature; for example, the New York Sandstone aquifers (Cambrian), the New York and New England carbonate rock aquifers (Silurian and Devonian), and the Marshall aquifer in Michigan (Mississippian) (fig. 3, table 1). The structural basins and arches control the depth to the aquifers, as shown in figure 4. As the depth to the top of the aquifers increases, water quality tends to degrade (as dissolved solids increase), and water use from these aquifers correspondingly declines. 


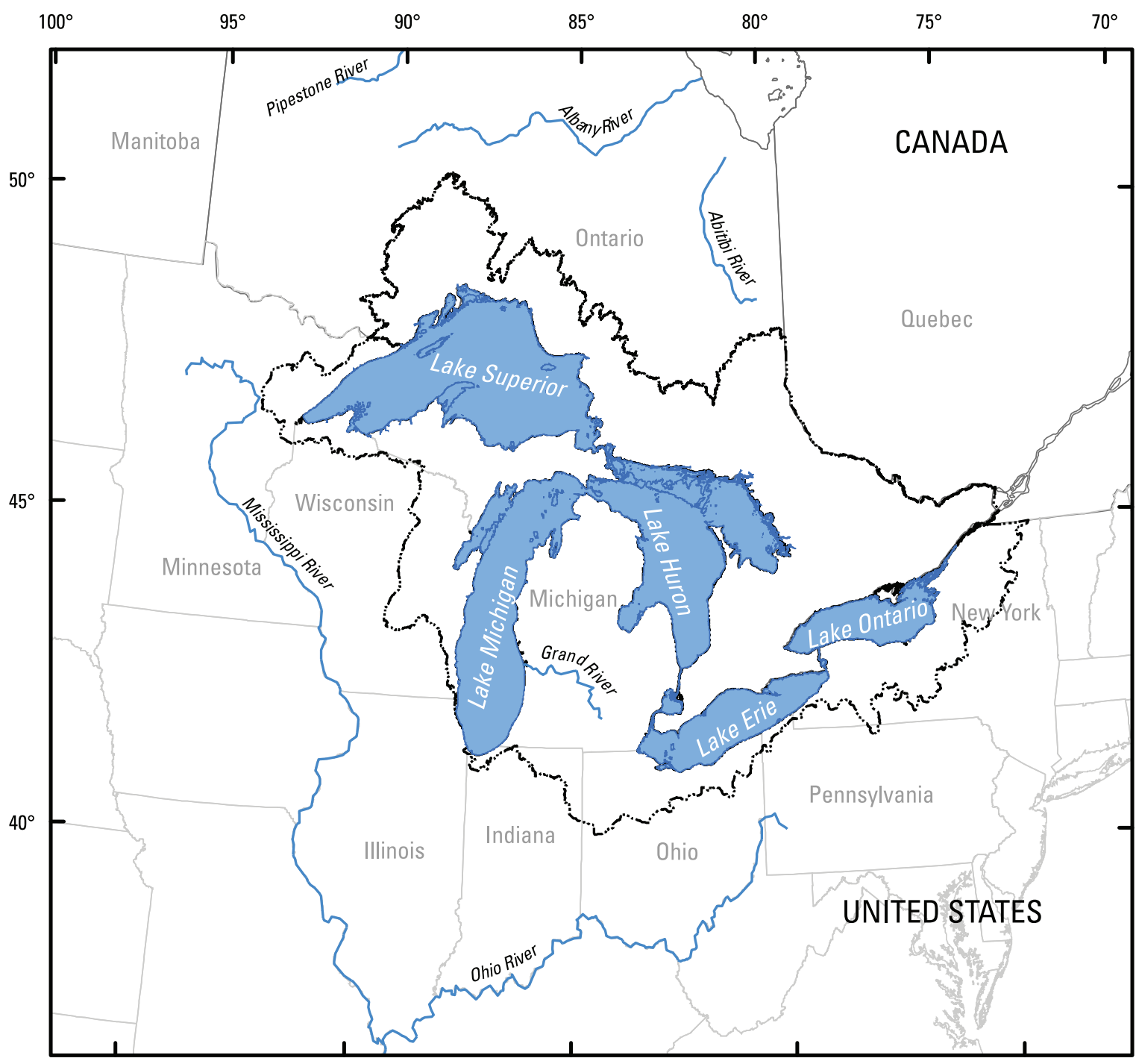

Base from U.S. Geological Survey digital data 1:2,000,000; 1992; NAD 83 Albers projection; meters

\section{EXPLANATION}

$\begin{array}{llll}0 & 50 & 100 & 200 \\ \end{array}$

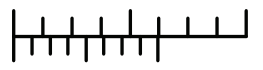
050100200 KILOMETERS

Great Lakes Basin surface-water divide

Figure 1. The Great Lakes surface-water basin. 


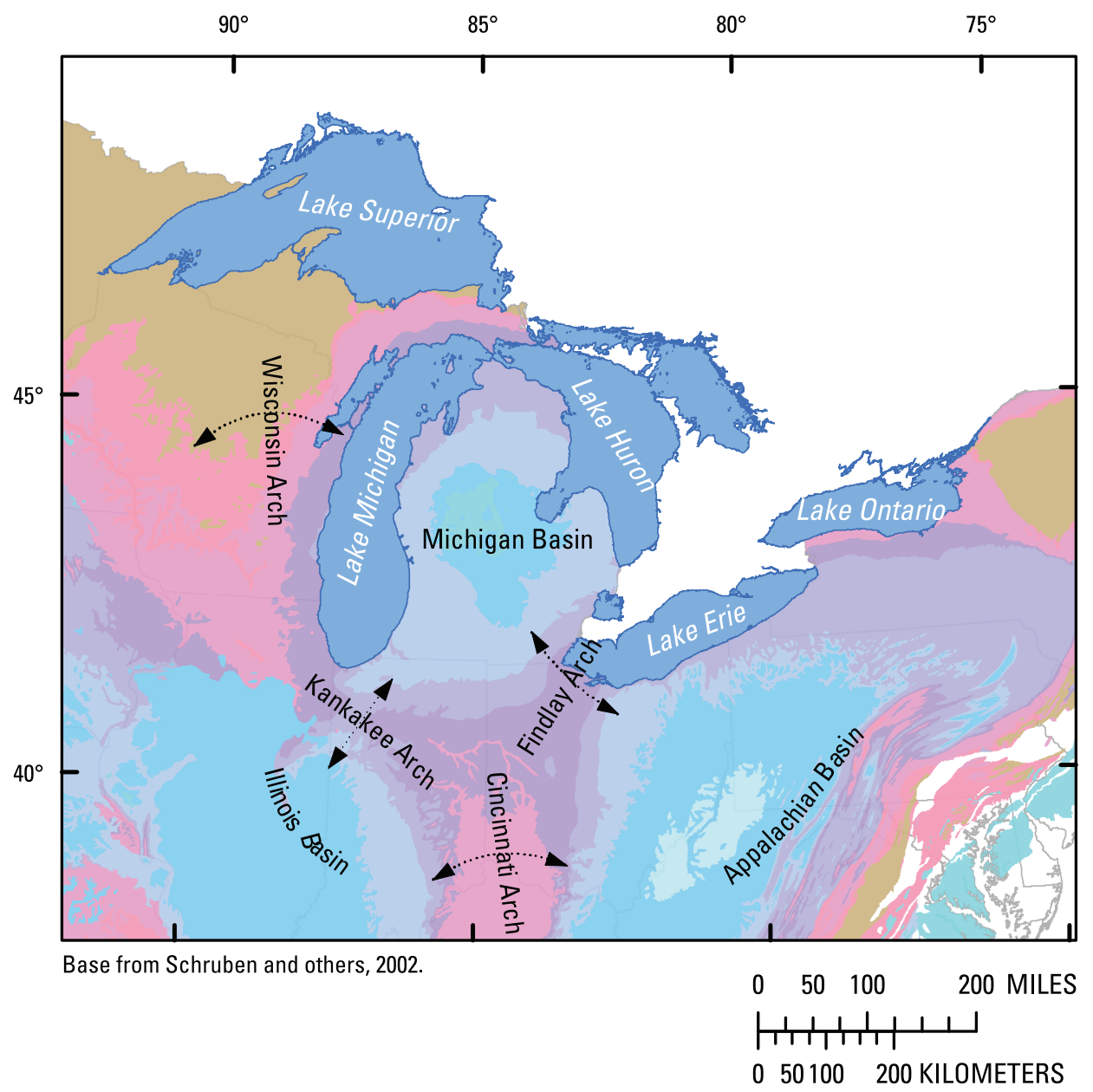

\section{EXPLANATION}

Age of geologic units
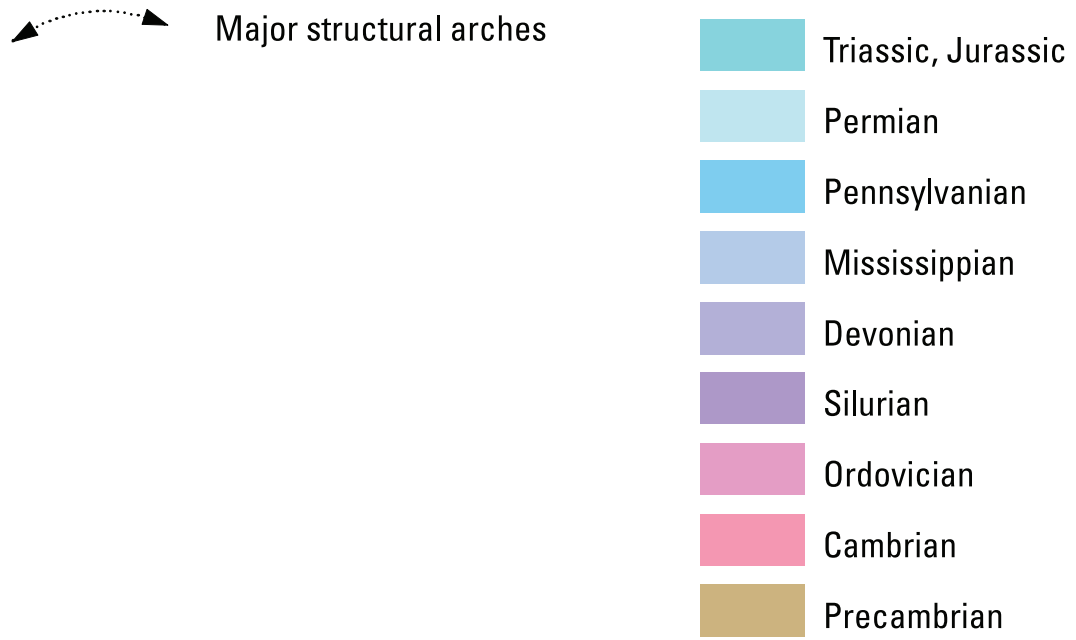

Figure 2. Bedrock geology of the Great Lakes region in the United States, including major structural features. 
Table 1. Generalized stratigraphic and hydrostratigraphic section corresponding to the Great Lakes Basin in the United States.

[Principal aquifer is defined as a rock unit that will yield usable quantities of water to wells (Miller, 1999; U.S. Geological Survey, 2003). Local rock units from Strobel and Bugliosi (1991); Lloyd and Lyke (1995)]

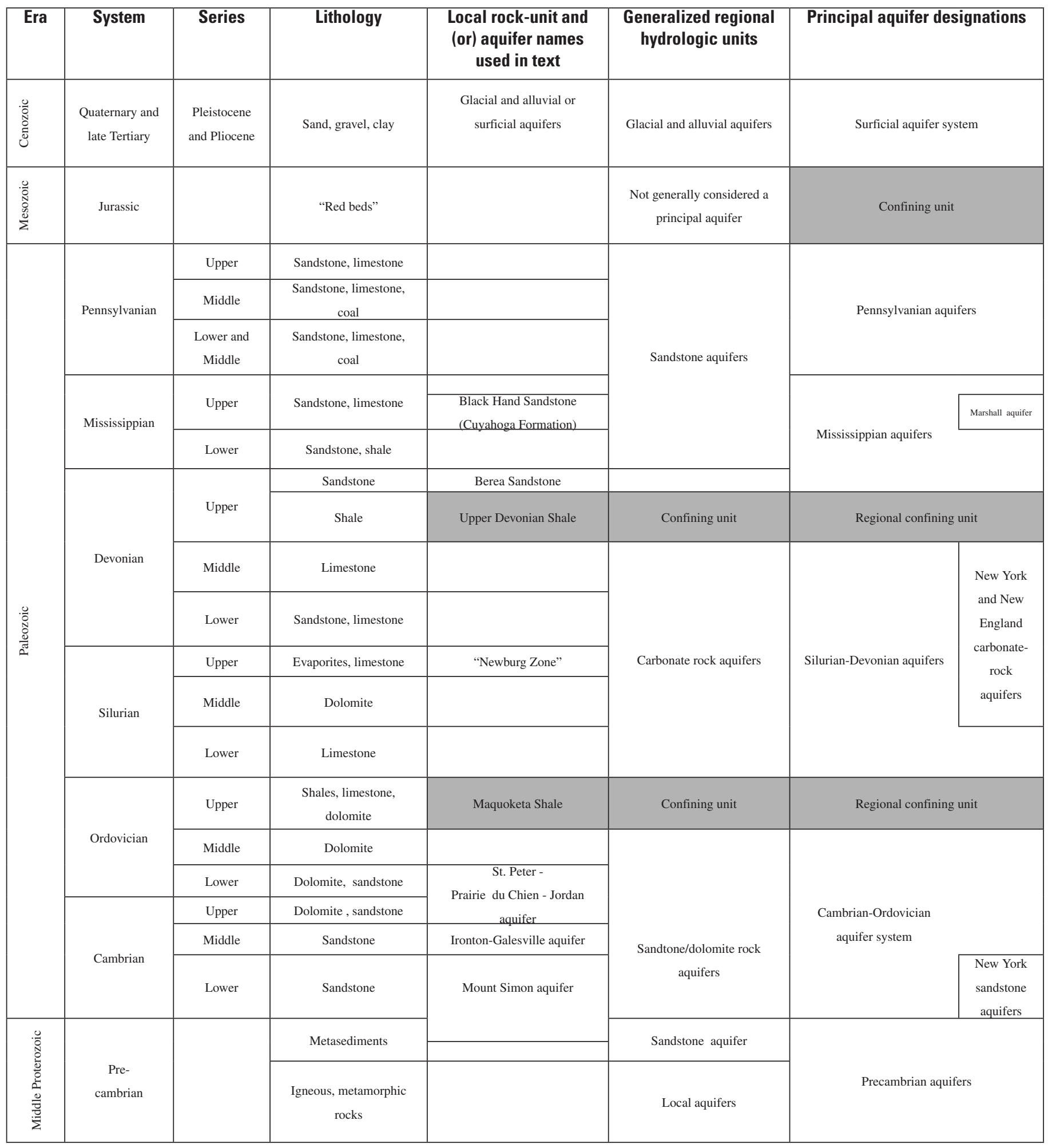




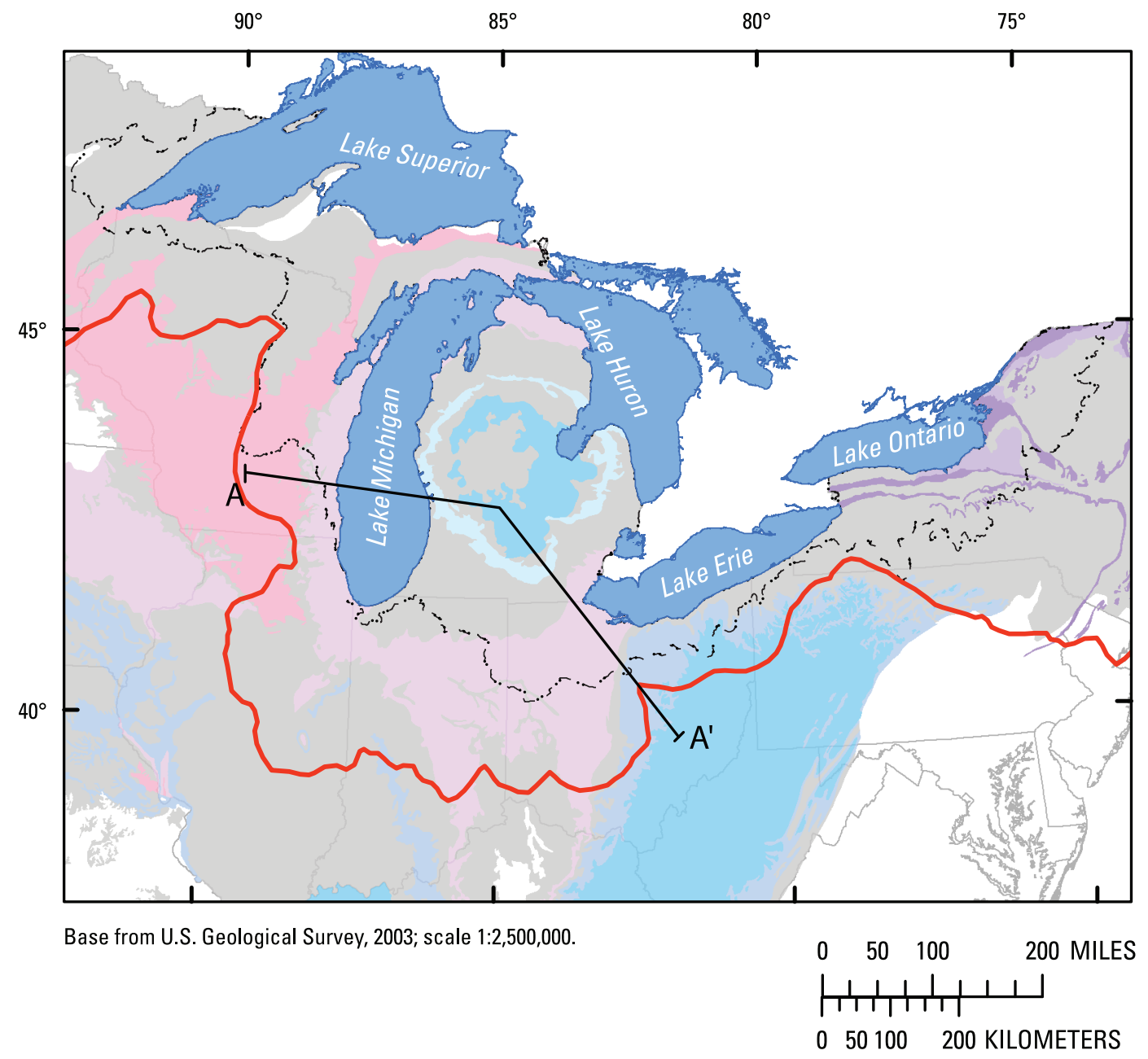

\section{EXPLANATION}

Principal bedrock aquifers

$ح$ Southern limit of Wisconsinan glaciation

ר. Great Lakes Basin surface-water divide

A-A' Line of hydrostratigraphic section (fig. 4)

\begin{tabular}{|l|}
\hline Pennsylvanian aquifers \\
\hline Marshall aquifer \\
\hline Mississippian aquifers \\
\hline New York and New England \\
carbonate-rock aquifers \\
\hline New York sandstone aquifers \\
Silurian-Devonian aquifers \\
Cambrian-Ordovician aquifer system \\
\hline Other rocks/Confining units
\end{tabular}

Figure 3. Principal bedrock aquifers in the Great Lakes region; surficial aquifer system primarily overlies area north of the limit of Wisconsinan glaciation. 


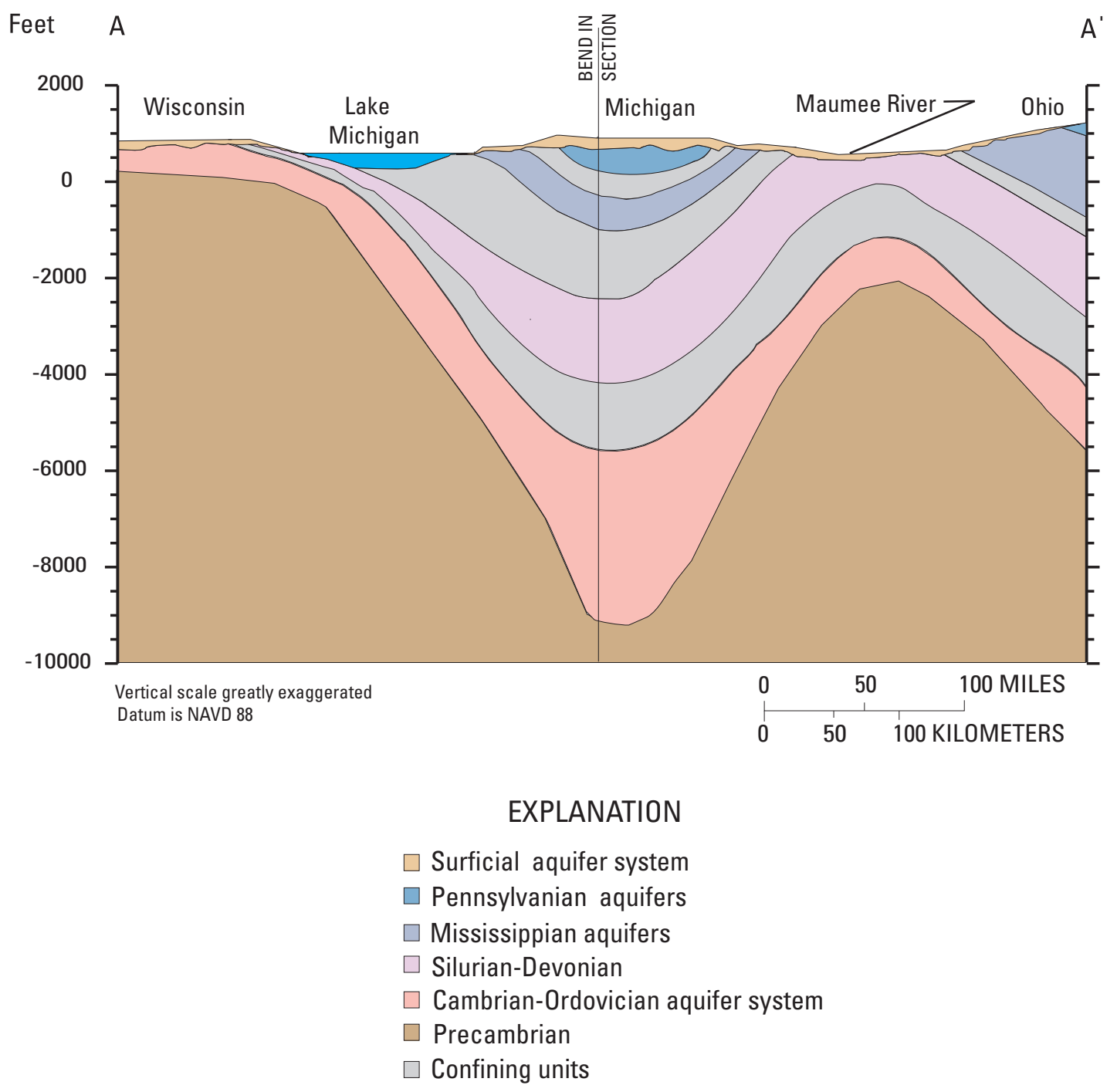

Figure 4. Generalized hydrostratigraphic section through the central part of the Great Lakes Basin, United States. (Line of section shown in fig. 3.) 


\section{Water Use}

Water demand in the Great Lakes Basin is predominantly met through surface-water withdrawals, including withdrawals directly from the Great Lakes. Total water use in the Great Lakes Basin for both Canada and the United States is approximately $850,000 \mathrm{Mgal} / \mathrm{d}$, and total ground-water use in the Great Lakes Basin (including the St. Lawrence River Basin) is about 1,500 Mgal/d (Solley and others, 1998; Grannemann and others, 2000; Great Lakes Commission, 2005). This calculation assumes that the surface- and ground-water divides coincide. However, an estimated $1,300 \mathrm{mi}^{3}$ of ground water is in storage in the Great Lakes Basin (Grannemann and others, 2000; W.F. Coon, U.S. Geological Survey, written commun., 2005).

In 1998, approximately 70 percent of the total groundwater withdrawals corresponding to the Great Lakes Basin came from aquifers in the Lake Michigan and Lake Erie Basins. Public and domestic supplies accounted for about 60 percent of the total ground-water withdrawals (Great Lakes Commission, 2005). The areas of largest ground-water withdrawals are in the Chicago-Milwaukee area near the Great Lakes Basin boundary.

\section{Methods}

The regional ground-water divides presented herein were obtained from reports on a variety of studies in and around the Great Lakes Basin in the United States. Ground-water divides were determined or adopted from previously published national and regional hydrogeologic studies of principal aquifers or aquifer systems, including potentiometric-surface maps that were based on water-level measurements or computer simulations. Interpretation of the location of the regional ground-water divides varies by author as well as by the data used. For this report, measured water-level data were considered to be a more accurate basis for depiction of ground-water flow than computer simulations. Regional divides constructed from published data and maps were digitized into a geographic information system; existing digital files were used where available. Any previously defined ground-water divides also were digitized. Relevant literature from subregional studies, as well as studies of locations near the boundaries of the Great Lakes Basin, also was examined to determine whether local-scale hydrogeologic studies contained potentiometric or ground-water-divide information that could be used to infer the position of the regional ground-water divide. The potentiometric surfaces from which the ground-water divides were derived were compiled from data collected at various times over the last 140 years, from predevelopment to present day (approximately 1865 to 2005).

\section{Compilation of Regional Ground-Water Divides}

The following sections describe the positions of the regional ground-water-flow divides in each of the principal aquifers corresponding to the Great Lakes Basin as derived from the previous investigations. A brief summary of the geology and hydrology of each of these principal aquifers is given, followed by a synopsis of the studies used to delineate the measured or simulated regional ground-water divides.

\section{Cambrian-Ordovician Aquifer System}

Located in the western part of the study area, the Cambrian-Ordovician aquifer system is a multiaquifer system comprising individual aquifers separated by leaky confining units. The Maquoketa Shale, a regional confining unit, caps the aquifer system where the aquifer system is not an outcrop or subcrop (fig. 4; table 1; Young, 1992, Olcott, 1992). Cambrian-Ordovician rocks are present as outcrops or subcrops under the glacial overburden along the Wisconsin and Kankakee Arches and the northern periphery of the Michigan Basin (fig. 2). These rocks also are deep underground (>2,000 ft) in areas such as in the Michigan Basin and in the northern Appalachian Basin, but they usually are not tapped by wells at these depths (fig. 2; Olcott, 1992; Lloyd and Lyke, 1995).

Three main aquifers make up the CambrianOrdovcian aquifer system: the St. Peter-Prairie du ChienJordan aquifer, the Ironton-Galesville aquifer, and the Mount Simon aquifer. Predominantly sandstone, each of these aquifers is composed of different types of rock with varying thicknesses, all of which affect how water flows through the system (Olcott, 1992; Lloyd and Lyke, 1995). The St. PeterPrairie du Chien-Jordan aquifer consists of fine- to mediumgrained, well-sorted St. Peter Sandstone; sandy dolomites from the Prairie du Chien Group; and fine- to coarse-grained, dolomitic Jordan Sandstone (Lloyd and Lyke, 1995). Thickness of the St. Peter-Prairie du Chien-Jordan aquifer ranges from 30-500 ft in the western part of the Great Lakes Basin to $250-1,250 \mathrm{ft}$ in the central part of the basin. The IrontonGalesville aquifer consists of fine- to coarse-grained Ironton and Galesville Sandstones with thicknesses ranging from 50 to $150 \mathrm{ft}$ near the Wisconsin Arch in Wisconsin and Illinois and averaging $150 \mathrm{ft}$ south of the Kankakee Arch (fig. 2). The Mount Simon aquifer, the lowermost aquifer of the system, consists of fine- to coarse-grained sandstones (Olcott, 1992). The Mount Simon aquifer is by far the thickest aquifer of the system. This aquifer ranges from very thin at the western edge of the system to about 1,500 $\mathrm{ft}$ in thickness along the southern part of the Wisconsin Arch to about 2,500 ft in thickness in the northern Illinois Basin (fig. 2; Olcott, 1992; Lloyd and Lyke, 1995).

Several hydrogeologic studies near the western extent of the Great Lakes Basin measured potentiometric surfaces or 
compiled water-level measurements. These data were used to locate the position of the ground-water divide for the Cambrian-Ordovician aquifer system at various times from predevelopment (late 1800s) to present day (2005) (fig. 5).

Mandle and Kontis (1992) present composite potentiometric-surface maps, based on a few measured hydraulic head data for predevelopment conditions, for the St. Peter-Prarie du Chien-Jordan aquifer and for the Mount Simon aquifer. This study modeled the general direction of ground-water flow, but was not intended to be used to determine the location of ground-water divides and therefore is not included in the figures. Burch (1991, 2002) and Young and others (1989) also created potentiometric-surface maps for predevelopment conditions in northern Illinois that were based on a few measurements of hydraulic head from approximately 1900 (fig. 5). The positions of the predevelopment Mount Simon and St. Peter-Prarie du Chien-Jordan ground-water divides are at best approximate because they are inferred from generalized potentiometric surfaces based on sparse water-level data and variable dates of studies or data-collection efforts.

Cotter and others (1969) compiled information from observation-well records and various reports dating from approximately 1940-65 to derive a potentiometric-surface map of the aquifers confined beneath the Maquoketa Shale regional confining unit in southern Wisconsin (fig. 5). In a more localized study, Delin and Woodward (1980) used sparse data from municipal wells in northeast Minnesota from 1970-1980 to map the potentiometric surface of the lower Cambrian-Ordovician aquifer system. The regional ground-water divide was then determined from these data (fig. 5).

As part of the USGS Regional Aquifer Systems Analysis (RASA) program, Mandle and Kontis (1992) generalized a potentiometric-surface map from measured hydraulic heads (1980) in the western part of the Great Lakes Basin, from which a ground-water divide for the St. Peter-Prairie du ChienJordan aquifer was derived. On the basis of previous studies, Young and others (1989) mapped the potentiometric surface in the Chicago-Milwaukee area (fig. 5). Lastly, Burch (2002) used measurements of potentiometric surfaces in northeastern Illinois to estimate ground-water flow directions from which ground-water divides were delineated for 1995 and fall 2000 (fig. 5).

The locations of ground-water divides for the CambrianOrdovician aquifer system, and aquifers within the system, also have been estimated by use of ground-water flow simulations (fig. 6). These simulations give a different depiction of ground-water flow in the system as compared to actual measurements of hydraulic head; therefore, the ground-water divides that were derived from these simulations also are different. Burch (1991) simulated predevelopment conditions (around 1900) and postdevelopment conditions (around 1985) in northeastern Illinois (fig. 6). Young and others (1989), as well as Mandle and Kontis (1992), simulated predevelopment conditions (around 1900) and postdevelopment conditions in 1980 in the Upper Midwest (fig. 6; Mandle and Kontis, 1992). The regional ground-water divides derived from measurements or simulations of hydraulic head show considerable variation temporally. Information regarding temporal variations in ground-water divides is presented in box 1.

Gupta and Bair (1997) used data from water and oil wells to simulate regional hydrodynamics of the Cambrian-Ordovician aquifer system and found that ground-water flow in the system is influenced by structural features, such as the Findlay Arch, and that cross-formational flow between regional aquifers is important even at depth in the Appalachian Basin (fig. 2). The regional ground-water divide based on simulated potentiometric maps of Gupta and Bair (1997) is quite different from that of previous authors because Gupta and Bair used a combination of oil and water hydraulic-head data; previous authors used only freshwater hydraulic head data. Results of the Gupta and Bair simulations are not shown in figure 6.

\section{Silurian-Devonian Aquifers}

The Silurian-Devonian aquifers are dominated by limestone and dolomite rock units but contain some regionally extensive evaporate deposits and interbedded shales. These carbonate-rock aquifers are only a few feet thick over the Cincinnati, Findlay, and Kankakee structural arches (table 1; figs. 2-4). As the units dip into the Mississippian, Illinois, and Appalachian Basins, they thicken to more than 2,300 ft and are overlain by an Upper Devonian shale regional confining unit. These aquifers are underlain by the Maquoketa Shale regional confining unit.

Regionally, the Silurian-Devonian aquifers function as a single hydrologic unit, although some highly permeable zones are known to exist (Strobel and Bugliosi, 1991; Bugliosi, 1999; for example, "Newburg Zone," table 1). Where the Silurian-Devonian aquifers subcrop near the structural arches, they are semiconfined by the surficial aquifer system and are widely tapped for water supplies (Bugliosi, 1999). In the structural basins, however, they are not generally used for water supply because (1) shallower freshwater aquifers, such as the Mississippian or surficial aquifer system are more accessible or (2) an increase in dissolved solids makes them less desirable as water sources (Bugliosi, 1999).

Ground-water divides were delineated from predevelopment (late 1800s) potentiometric-surface maps of the Silurian-Devonian aquifers in western Indiana and eastern Illinois developed by Mandle and Kontis (1992) (fig. 7). As part of studies in the USGS RASA program, Mandle and Kontis (1992) also simulated 1980 conditions in the Silurian-Devonian aquifers (fig. 7). Kay and others (1996) show that flow in the Silurian-Devonian aquifers near the Great Lakes Basin divide at the southern edge of Lake Michigan is influenced by bedrock topography and pumping. In southeastern Wisconsin, the Southeastern Wisconsin Regional Planning Commission (2002) and Feinstein and others (2004) describe the Silurian aquifers as being part of a shallow flow system, which includes the overlying sand and gravel aquifers. The shallow flow system is described as being under water-table conditions 


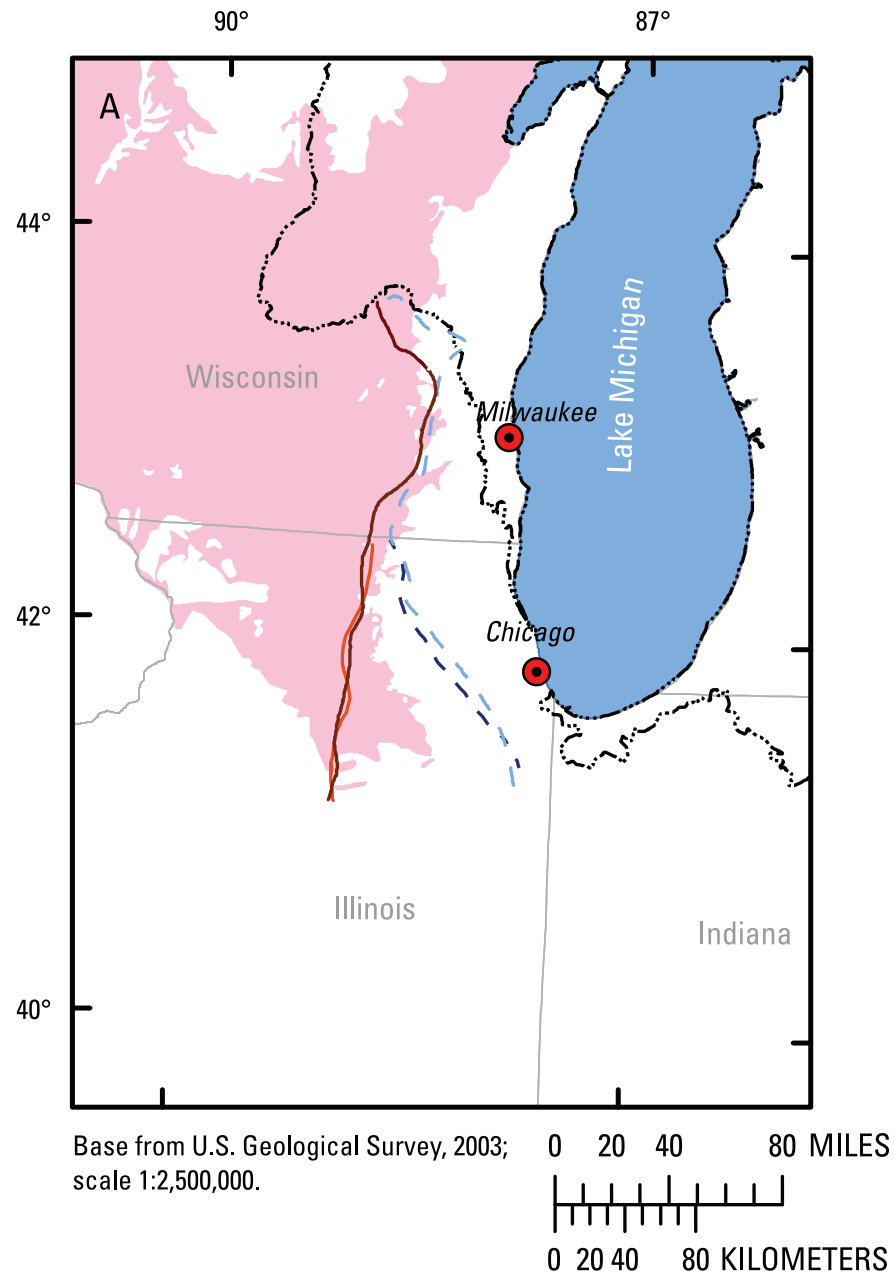

EXPLANATION

Great Lakes surface-water divide

Cambrian-Ordovician aquifer system

Map A

Cambrian-Ordovician aquifer system

- - - Predevelopment (Burch, 1991, 2002)

$\frown 2000$ (Burch, 2002)

- Predevelopment (Young and others, 1989)

1985 (Young and others, 1989)

Map B

Lower Cambrian-Ordovician aquifer system

1970-80 (Delin and Woodward, 1980)

Map C

Cambrian-Ordovician aquifer system

$\because \because . .$. Young, 1992

$\because \because . .$. Cotter and others, 1969

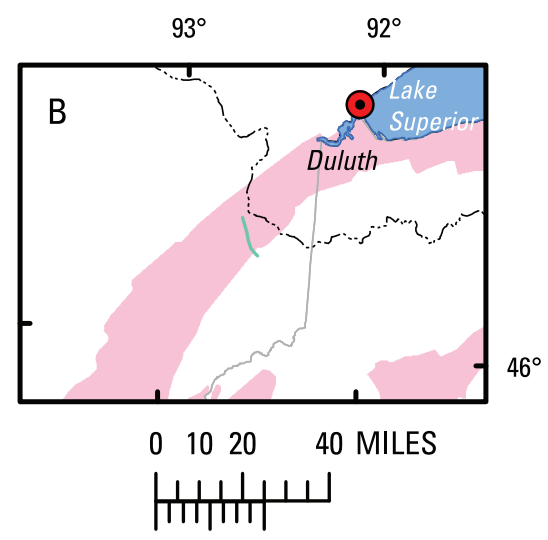

0102040 KILOMETERS

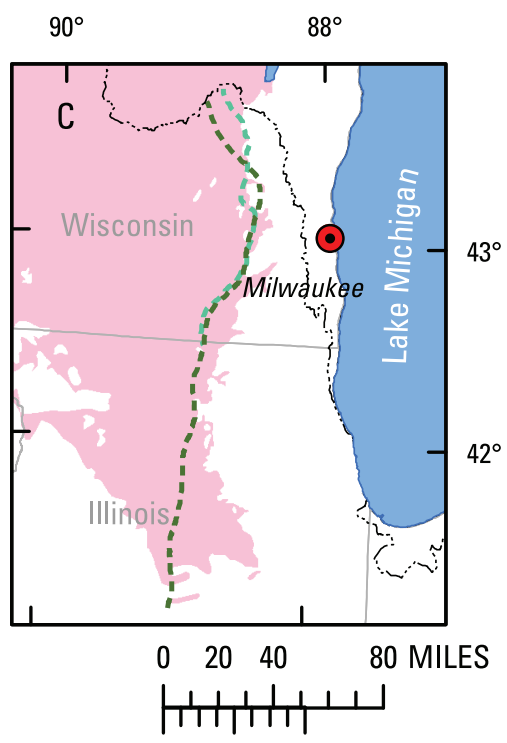

$02040 \quad 80$ KILOMETERS

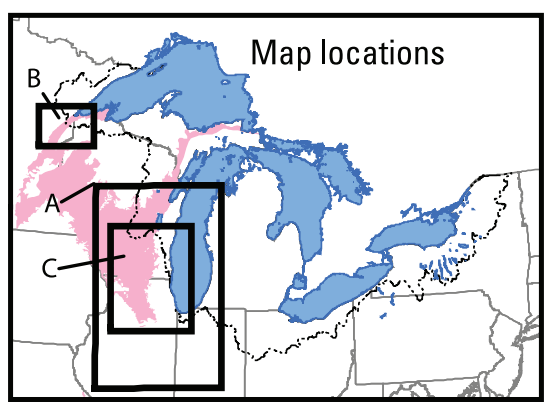

Figure 5. Measured or inferred ground-water divides in the Cambrian-Ordovician aquifer system in the Great Lakes region at different times from predevelopment through 2000. (Predevelopment is approximately 1865-90; lines dashed where approximate.) 


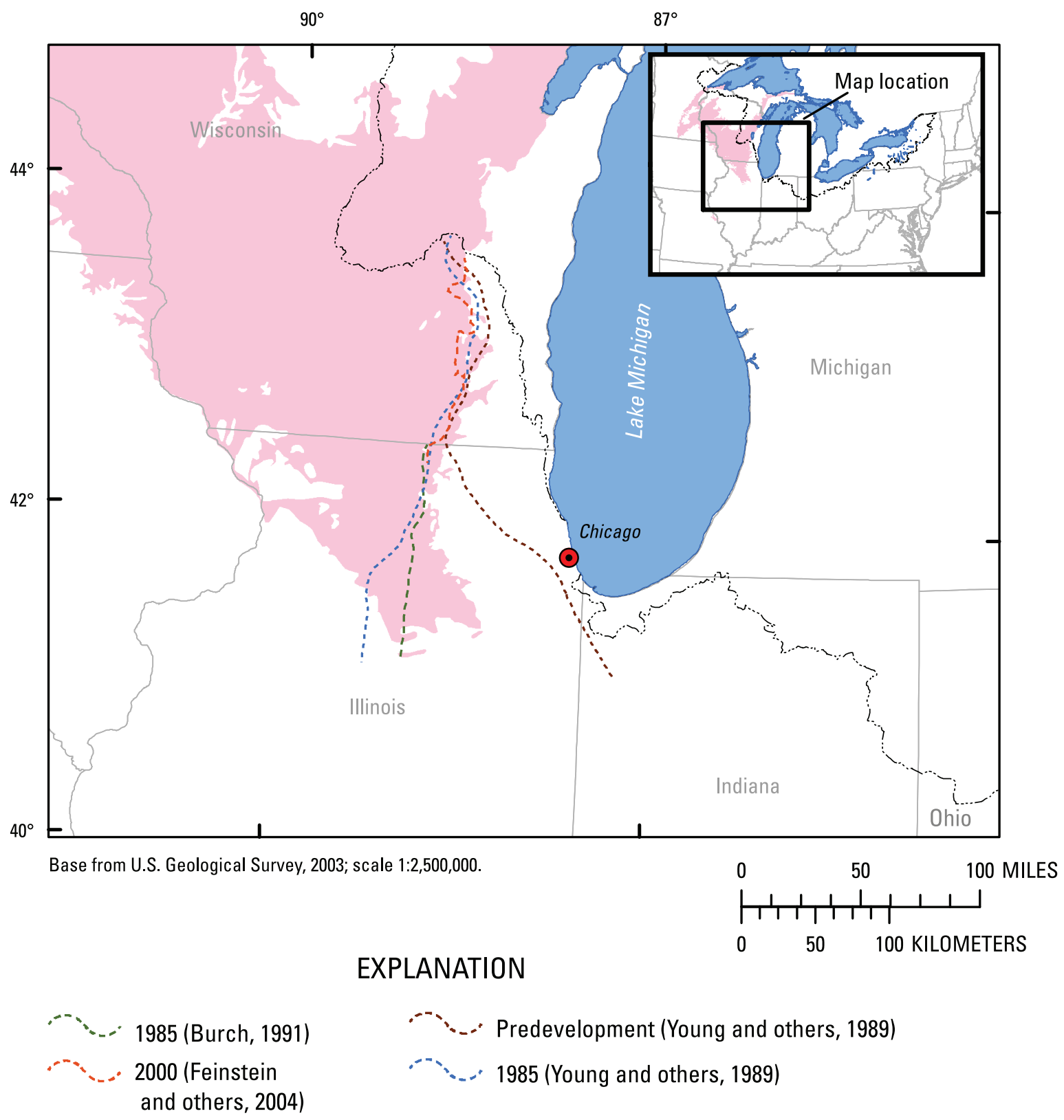

\section{Great Lakes Basin surface-water divide \\ Cambrian-Ordovician aquifer system}

Figure 6. Simulated ground-water divides in the Cambrian-Ordovician aquifer system in the Great Lakes region at different times from predevelopment through 2000. (Predevelopment is approximately 1865-90; lines dashed where approximate.) 


\section{Box 1. Factors Affecting Position Of Regional Ground-Water Divides}

Ground-water levels change in response to additions and losses of water to the regional hydrologic system (U.S. Geological Survey, 2005a); in turn, the position of the ground-water divide can shift. Human activities that might affect the position of ground-water divides include land-use and land-management practices, such as pumping, stream channelization, canal building, mining, and urbanization; the resulting changes may take place over anywhere from months to decades. Natural factors can also affect positions of local and regional ground-water divides but usually are associated with longterm (decades/centuries/millennia) changes in ground-water flow. Such factors include longterm changes in precipitation, erosion, and crustal rebound from glaciation. The following three discussions help illustrate the range, complexity, and interaction of human activities and natural factors affecting groundwater flow and divides.

\section{Pumping}

Long-term pumping can affect the position of regional ground-water flow divides by diverting water that would normally discharge to surface water or toward the open interval of a well (U.S. Geological Survey, 2005a; Sheets and others, 2005). Hydrologic studies within the Cambrian-Ordovician aquifer system have shown that regional ground-water divides have moved over time, primarily because of ground-water pumpage (figs. 5, 6, and B-1). Pumping from deep wells completed in the Cambrian-Ordovician aquifer system in the Chicago and Milwaukee region is substantial (33.5 Mgal/d in 2000) and has had a great effect on water levels in these areas, shifting the location of the regional ground-water divide (fig. B-1; Sasman and others, 1960; Sheets and others, 2005). Burch $(1991,2002)$ used both water-level measurements and simulations to illustrate the effects of pumping on groundwater flow and the position of the ground-water divides in the Chicago area (figs. 6 and B-1); Sasman and others (1960) did a

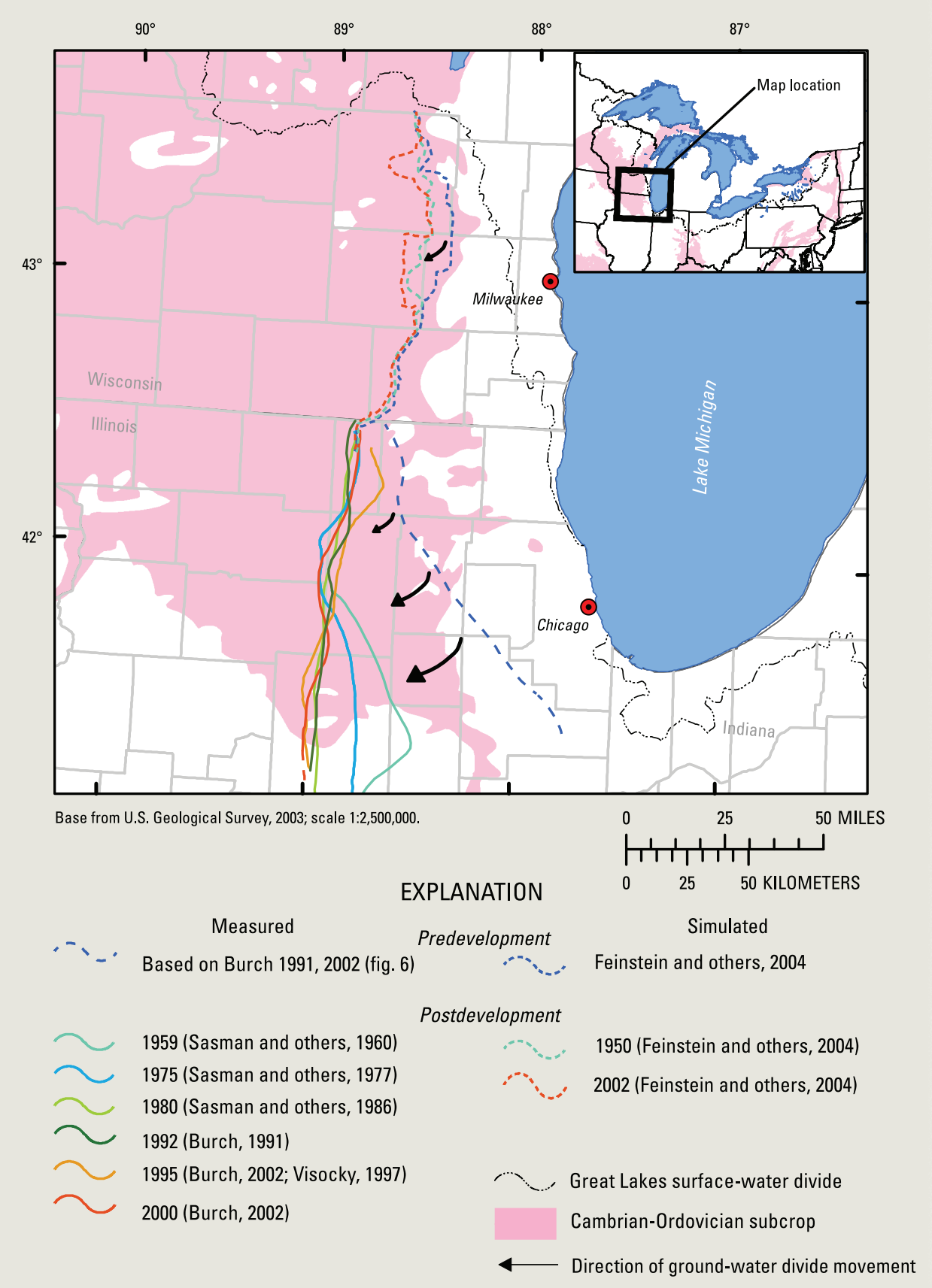

Figure B-1. Measured and simulated ground-water divides in the Cambrian-Ordovician aquifer system in northeast Illinois from predevelopment through 2000. (Predevelopment is approximately 1865-90; lines dashed where approximate.) 
similar study using only water-level measurements (fig. B-1). Russell (1963) used measured data (220 observation wells) to map the potentiometric surface of the Chicago area in 1961 (fig. B-1). Pumpage from the greater Chicago-Milwaukee area has caused the potentiometric surface in the Cambrian-Ordovician aquifer system to decline regionally (Cotter and others, 1969). Figure B-1 shows the predevelopment and postdevelopment positions of the regional ground-water divides of the Cambrian-Ordovician aquifer system in the Milwaukee area (Feinstein and others, 2004; Southeastern Wisconsin Regional Planning Commission, 2002).

\section{Recharge}

Changes in areal (or diffuse) recharge to aquifer systems also can alter the position of local and regional groundwater divides. Recharge changes over a large region, such as the Great Lakes, and during a long time period may affect ground-water storage and water availability but may not appreciably change ground-water flow directions or the position of regional ground-water divides (Sheets and others, 2005). If these changes affected the entire area equally, ground-water levels would tend to rise or decline over the entire area. However, these regional and long-term changes in recharge are difficult to assess (Alley and others, 2002; Neff, 2006). Local variability in recharge due to changes in precipitation patterns or urbanization at or near the regional ground-water divide could possibly alter the position of the ground-water divide, because this variability affects ground-water flow patterns (Alley and others, 2002).

The occurrence and rate of areal recharge is a function of many variables, including topography, land use, intensity and distribution of precipitation, and air temperature (Walton, 1965). Each of the factors affecting areal recharge can be altered, at different temporal and spatial scales, through human activity or natural changes. As a result, ground-water levels and ground-water divides can be altered to differing degrees.

Agricultural drainage is an example of human-influenced changes to ground-water recharge that may have affected the positions of the regional ground-water divides. In the middle 1800s through the early 1900s, settlers in the Great Lakes States used various techniques of draining wetlands to increase agricultural production (Zucker and Brown, 1998). According to a 1985 survey, from 10 to 50 percent of all cropland in the Great Lakes States has been drained for agricultural purposes (Zucker and Brown, 1998). The wholesale lowering of the water table in specific areas of these states may influence ground-water flow and positions of ground-water divides. Eberts and George (2000) indicate that lowering of the water table in the Great Swamp of northwestern Ohio may have influenced regional ground-water recharge to the surficial aquifer system and to the Silurian-Devonian aquifers and may also have affected overall ground-water flow patterns within the Maumee River Basin. Therefore, the positions of the regional ground-water divides of the surficial aquifer system and the Silurian-Devonian aquifers may have been altered as a result of this large-scale dewatering.

\section{Crustal rebound}

Long-term isostatic or crustal rebound from release of pressure due to continental glaciations may also affect the position of the ground-water divides over long time periods. In the Great Lakes Basin, after the last of the continental glaciers retreated (approximately 12,500 years ago), the continental crust began rebounding at a rate of approximately 2.8 in/yr, but has slowed since then to a rate of about $0.4 \mathrm{in} / \mathrm{yr}$ in areas of greatest change (Clark and Persoage, 1970). Based on recent measurements with long-term global positioning systems, Lake Superior, Lake Michigan, Lake Huron, and Lake Ontario are rebounding at a rate of $0.07,0.04,0.06$, and $0.04 \mathrm{in} / \mathrm{yr}$, respectively (Shum and others, 2002). These rates approximately correspond to those shown on maps based on older data. These maps show isostatic rebound ranges from 0 to 1.75 feet per century in the Great Lakes Basin, with the largest rebounds in the area near Lake Superior (Neff and Nicholas, 2005; Clark and Persoage, 1970). This uplift may continue to preferentially change the horizontal and vertical ground-water flow gradients and alter the position of both regional and local ground-water flow divides over long periods of time. Surface topography, which can affect recharge rates, also is affected by erosion over this long timeframe. 
(unconfined). The study area for Feinstein and others (2004) spans the regional ground-water divide, and their simulations show predevelopment water levels in the water-table aquifer.

Eberts and George (2000) examined water-level measurements in the Silurian-Devonian aquifers from 1992. They found that ground-water flow in the Silurian-Devonian aquifers over the Cincinnati Arch generally mimics surface topography and that the configuration of the potentiometric surface in the Silurian-Devonian aquifers is similar to that in the surficial aquifer system. Potentiometric high areas in the SilurianDevonian aquifers mimic topographic highs in west-central Ohio and highs near the southern limit of the aquifer along the border between Indiana and Ohio; potentiometric low areas are coincident with major rivers that drain the area. Therefore, regional ground-water divides, based on work by Eberts and George (2000), are near-but not coincident with-the Great Lakes regional surface-water divide (fig. 7). Greeman (1991) also saw a pattern similar to the one identified by Eberts and George (2000) and determined that the areal difference between the location of the regional surface-water divide and ground-water divide in Indiana is about 1,000 $\mathrm{mi}^{2}$.

\section{Mississippian Aquifers}

Rocks of Mississippian age occupy much of the Michigan Basin, where they are primarily composed of siltstone and medium-grained sandstone. In the Illinois Basin, Mississippian rocks consist of thick-bedded limestones and sandstones. In the northern Appalacian Basin, Mississippian rocks are composed of limestone, sandstone, and shale (fig. 2; Olcott, 1992; Lloyd and Lyke, 1995).

The Mississippian aquifers occur in thin bands around the structural basins and are dominated by sandstone (figs. 2 and 8). In the Michigan Basin, the principal Mississippian aquifer is the Marshall aquifer, in the Marshall Sandstone. This aquifer is widely used for water supply, especially in Michigan. However, it is entirely within the boundaries of the Great Lakes Basin, and any ground-water divides within the Marshall aquifer are not regional divides. This unit ranges in thickness from 50 to about 1,000 ft. Limestone and shale are present with sandstone in the northern Appalachian Basin. The Black Hand Sandstone (within the Cuyahoga Formation) (maximum thickness of $600 \mathrm{ft}$ ) and the Berea Sandstone (maximum thickness of $100 \mathrm{ft}$ ) are the dominant rock units (Olcott, 1992; Lloyd and Lyke, 1995). Although at least part of the Berea Sandstone is Devonian in age, it is included with the Mississippian aquifers in this report because of its geological and hydrological similarity (table 1). These are the principal Mississippian rock units used for water supply that are also near the Great Lakes Basin surface-water divide (figs. 3 and 8).

In 1986, Eberts and others (1990) measured the potentiometric surface at 22 locations in the Berea Sandstone in northeastern Ohio. They found that ground-water flow was not simply in the downdip direction but toward the subcrops or outcrops of the unit. Therefore, the regional ground-water flow divide in this area (fig. 8) separates ground-water flow going downdip (toward the Ohio River Basin) from flow that travels toward the subcrop areas, eventually discharging to Great Lakes Basin tributaries. Jagucki and Lesney (1995) found similar results in this same area from water-level data for 31 wells collected in 1994 (fig. 8).

\section{Pennsylvanian Aquifers}

The Pennsylvanian aquifers are dominated by sandstone and limestone, with minor amounts of siltstone, shale, and a repeating sequence of sedimentary beds that include underclay, gypsum, and coal (table 1; Olcott, 1992; Lloyd and Lyke, 1995). Distributed as bands along the edges of the structural basins, they reach their greatest extent in the central part of the Michigan Basin (fig. 3). Aquifer thickness is highly varied. Thickness ranges from 50 to more than $700 \mathrm{ft}$ in the Michigan Basin and exceeds 1,500 ft in some areas of the northern Appalachian Basin (Lloyd and Lyke, 1995). Only the Pennsylvanian aquifers in the northern Appalacian Basin are near the Great Lakes Basin surface-water divide; therefore, these are the only aquifers of concern to this investigation (figs. 3 and 8).

Little information on regional ground-water divides is available for the Pennsylvanian aquifers (fig. 8). Eberts and others (1990), Eberts (1991), and Jagucki and Lesney (1995) measured potentiometric surfaces of the Pennsylvanian aquifers and surficial aquifer system in northeast Ohio for the years 1986, 1987, and 1994, respectively. On the basis of these results, Jagucki and Lesney (1995) believe that the Pennsylvanian aquifers and the surficial aquifer system act as one hydrostratigraphic unit. This similarity also extends to the locations of the surface- and ground-water divides.

\section{Surficial Aquifer System}

The uppermost and most widespread aquifer system corresponding to the Great Lakes Basin is the surficial aquifer system. This system is the result of material deposited during multiple advances of continental glaciers during the Pleistocene and Pliocene Epochs (table 1; Olcott, 1992). The surficial aquifer system is present throughout the Great Lakes region (fig. 3). Glacial deposits in the Great Lakes region have varied lithology and complex stratigraphy derived from the different materials of the predominant rock types in the glaciers' paths (Olcott, 1992). For example, glacial advances north of the Wisconsin Arch (fig. 2) originated from both the northwest-depositing gray calcareous till that contains fragments of limestone and shale — and the northeast_leaving behind a reddish, sandy, noncalcareous till (Olcott, 1992). Southeast of the Wisconsin Arch and south of the Michigan Basin, surficial deposits are the remnants of the sandstone and crystalline bedrock encountered by the glacial advances in these areas. Sand and gravel deposits, both at land surface and buried deep 


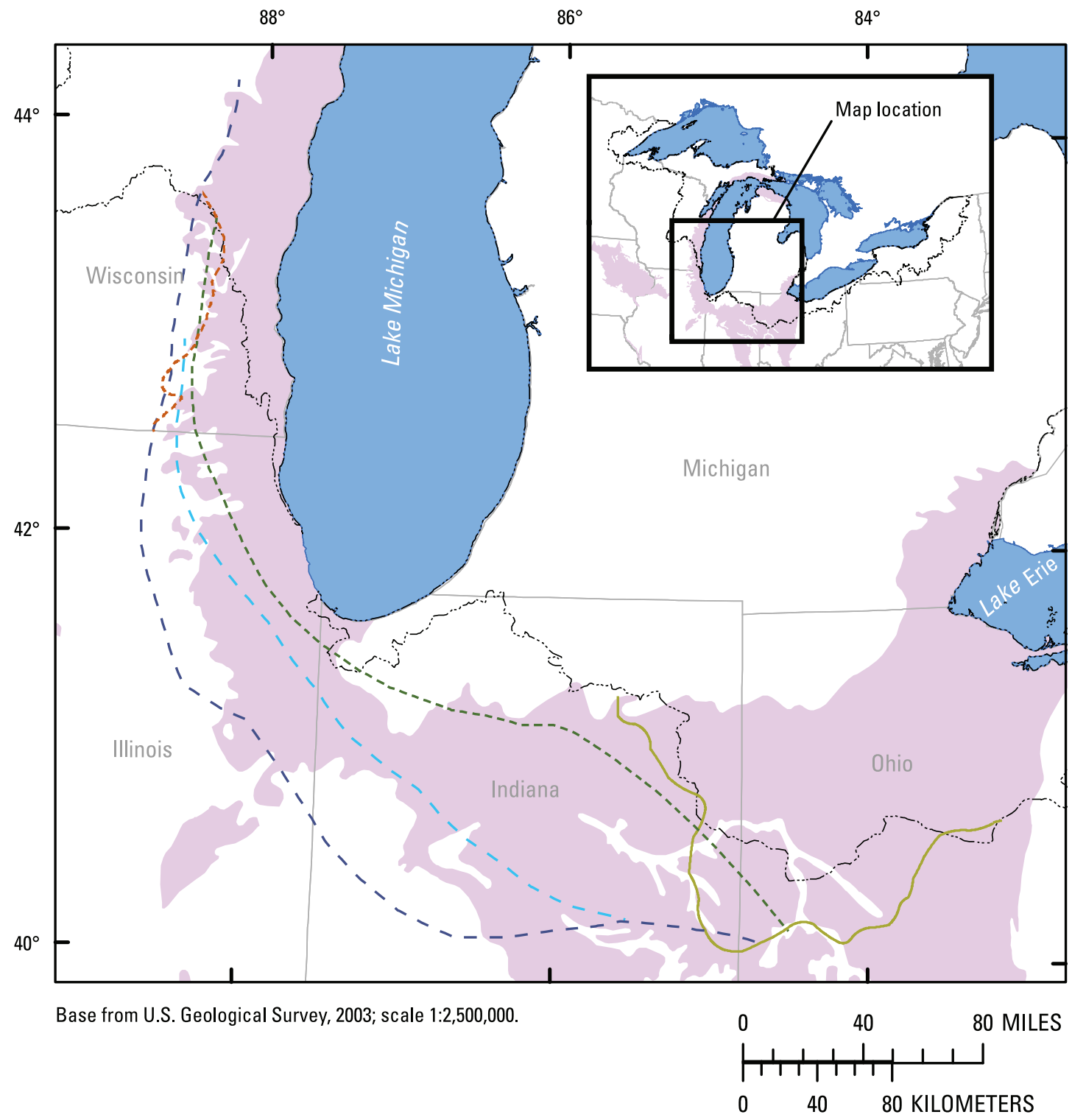

EXPLANATION

Measured

..... Predevelopment (Mandle and Kontis, 1992)

1990 (Eberts and George, 2000)
Simulated

-... Simulated predevelopment

(Mandle and Kontis, 1992)

.... Simulated predevelopment

(Feinstein and others, 2004)

$\because$ Simulated 1980 (Mandle and Kontis, 1992)

Great Lakes Basin surface-water divide

Silurian-Devonian aquifer subcrops

Figure 7. Simulated and measured ground-water divides in the Silurian-Devonian aquifer in the Great Lakes region at different times from predevelopment through 1990. (Predevelopment is approximately 1865-90, lines dashed where approximate.) 

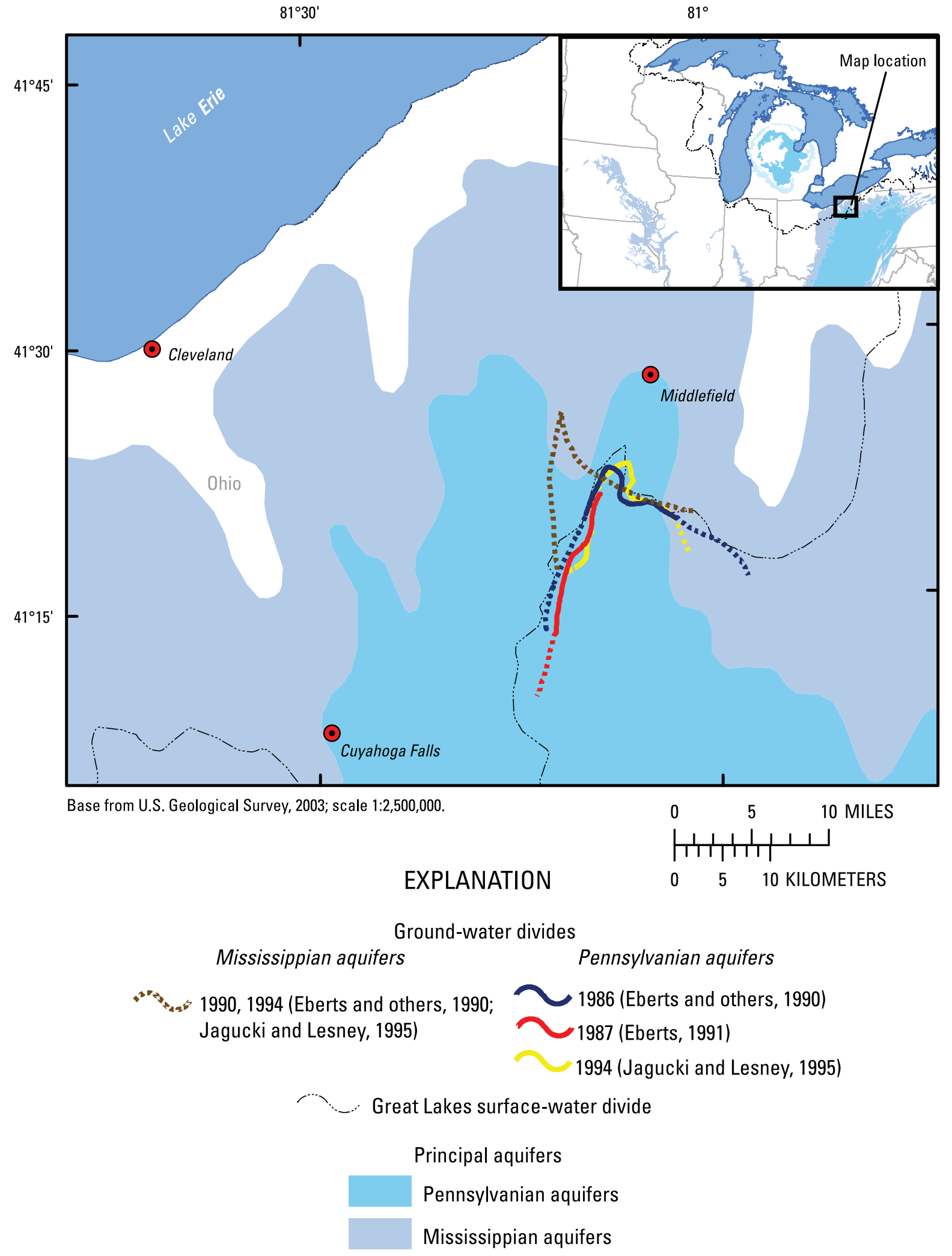

Figure 8. Measured ground-water divides in the Mississippian and Pennsylvanian aquifers in the Great Lakes region (lines dashed where approximate). 
beneath finer grained material, make up the surficial aquifer system north of the Cincinnati Arch and east of the Findlay Arch (fig. 2; Lloyd and Lyke, 1995).

In the western part of the Great Lakes Basin, the thickness of the surficial deposits generally ranges from 50 to $400 \mathrm{ft}$; deposits in the northern part of the Michigan Basin can be as much as 1,000 ft thick (Olcott, 1992). Thickness of surficial deposits in the central to eastern part of the Great Lakes Basin ranges from less than $100 \mathrm{ft}$ to between 400 and $600 \mathrm{ft}$ in buried valleys (Lloyd and Lyke, 1995).

Multiple studies have measured the potentiometric surfaces for confined, semiconfined, and unconfined aquifers in the surficial aquifer system near the periphery of the Great Lakes Basin (fig. 9). For northeastern Minnesota, Myette (1986) used finite-difference numerical models from Trescott and others (1976) to simulate ground-water flow in the sandplain aquifers; the regional ground-water divide was interpreted from these results (fig. 9). A series of investigations in the late 1960s and 1970s by the U.S. Geological Survey, in cooperation with the Minnesota Department of Natural Resources, the Wisconsin Geological and Natural History Survey, and Indiana Department of Natural Resources, used compiled well records, previously published reports, and some measured water levels to determine generalized potentiometric-surface maps for the shallow (primarily glacial) aquifers in the northwestern part of the Great Lakes Basin (fig. 9; Minnesota: Helgesen and others, 1973, 1976; Lindholm and others, 1979; Oakes and Bidwell, 1968; Olcott and others, 1978. Wisconsin: Cotter and others, 1969; Devaul and Green, 1971; Oakes and Hamilton, 1973; Oakes and Cotter, 1975; Olcott, 1968; Skinner and Borman, 1973; Young and Hindall, 1972a, 1972b. Indiana: Pettijohn and Davis, 1973; Tate and others, 1973). Oakes and Hamilton (1973) and Delin and Woodward (1980) mapped the water table for parts of Wisconsin during hydrologic studies of the Cambrian-Ordovician aquifer system (fig. 9). Kammerer (1995) created a Wisconsin water-table map based on county ground-water studies or inferred from USGS topographic maps; that map includes data from glacial and shallow Silurian dolomite or Cambrian-Ordovician carbonate or sandstone aquifers (fig. 9). Each of the studies found little difference between the regional surface-water and ground-water divides because shallow ground-water flow generally mimics land-surface topography. Slight differences in the divides were mostly attributed to local landforms (Devaul and Green, 1971) or precipitation (Lindholm and others, 1979). Young and others (1989) also produced a generalized water-table map in southeastern Wisconsin and northeastern Illinois (fig. 9). The regional ground-water divide that can be inferred from that map deviates from the regional surfacewater divide (fig. 9); however, Young and others (1989) state that their water-table map does not capture local and intermediate ground-water flow systems, which probably form a ground-water divide coincident with the surface-water divide.

The Indiana Department of Natural Resources (IDNR) used static water levels from confined and unconfined wells at various depths to create composite potentiometric-surface maps of shallow aquifers in parts of northern Indiana bounded by the regional surface-water divide (Indiana Department of Natural Resources, 1987, 1990, 1994). From these maps, a regional ground-water divide can be derived (fig. 9). However, in these reports, no distinction was made between wells completed in the glacial aquifer system and bedrock aquifers, so any variations between the surface-water divide and ground-water divide cannot be attributed to one aquifer system or another. In the area underlain by the Silurian-Devonian aquifers, Eberts and George (2000) developed a composite regional potentiometric-surface map based on 1992 drillers' logs of the surficial aquifer system and shallow bedrock. They used this map to determine that the depth to the regional water table mirrors land-surface elevation. This indicates that regional ground-water flow divide for the surficial aquifer system in this area approximates the regional surface-water divide (fig. 9). Eberts and George (2000) also used long-term water levels to infer that the surficial aquifer system is in a state of dynamic equilibrium and that the regional ground-water divide had not been altered by anthropogenic or other factors during the 10 years prior to their study.

Randall and others (1988) modeled seasonal groundwater levels in northern New York, using a sparse data set of eight wells, to create potentiometric-surface maps from which the ground-water divide was determined (fig. 9). Kappel and others (2001) made three sets of ground-water- level measurements from spring through fall 2000; these data were used to create potentiometric maps in northern New York from which regional ground-water divides were derived (fig. 9).

\section{Composite Regional Ground-Water Divides for Consolidated-Rock Aquifers}

A composite regional ground-water divide for the five consolidated-rock principal aquifers was estimated by use of the most recent information available from the compilation used in this report, including modeling studies and actual measurements of potentiometric surfaces (fig. 10). For areas where no data were available, the position of the composite regional ground-water divide was estimated from topography, geologic structure, surficial aquifer ground-water divides (if available), and smaller-scale studies within the regional aquifer systems.

A combination of model simulations and well-log information was used to map potentiometric surfaces from northwestern Ohio to southeastern Wisconsin from which the position of the ground-water divide was estimated (Feinstein, 2004; Southeastern Wisconsin Regional Planning Commission, 2002; Eberts and George, 2000) (fig. 10). These studies closely tied the Silurian-Devonian aquifers to the shallower sand and gravel flow systems, such as the surficial aquifer system. The ground-water divides for the Silurian-Devonian aquifers, where no documented data were available, were 


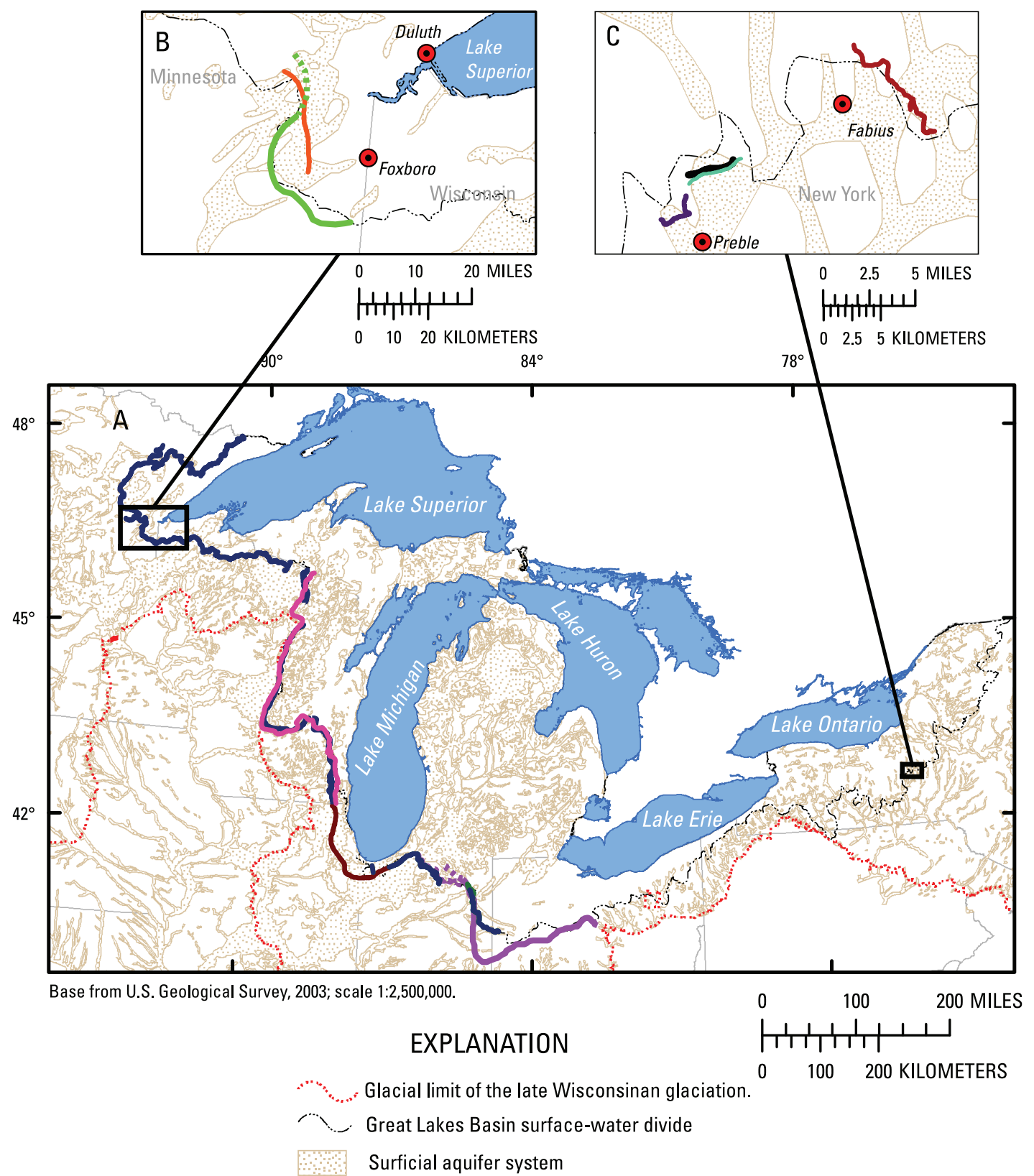

Map A

Map B

Olcott, P.G., 1968; Oakes and Bidwell, 1968; Cotter and others, 1969; Devaul and Green, 1971; Young and Hindall, 1972a; Young and Hindall, 1972b; Helgesen and others, 1973; Oakes and Hamilton, 1973 ; Skinner and Borman, 1973; Oakes and Cotter, 1975; Helgesen and others, 1976; Olcott and others, 1978; Lindholm and others, 1979.

Pettijohn and Davis, 1973; Tate and others, 1973; Indiana Department of Natural Resources, 1987 and 1990.

Kammerer, 1995

1970-80 (Delin and Woodward,1980) 1979-82 (Myette, 1986)

Young and others, 1989.

1992 (Eberts and George, 2000)

Figure 9. Regional ground-water divides of the surficial aquifer system in the Great Lakes region from different time periods from 1970 through 2001 (lines dashed where approximate). 


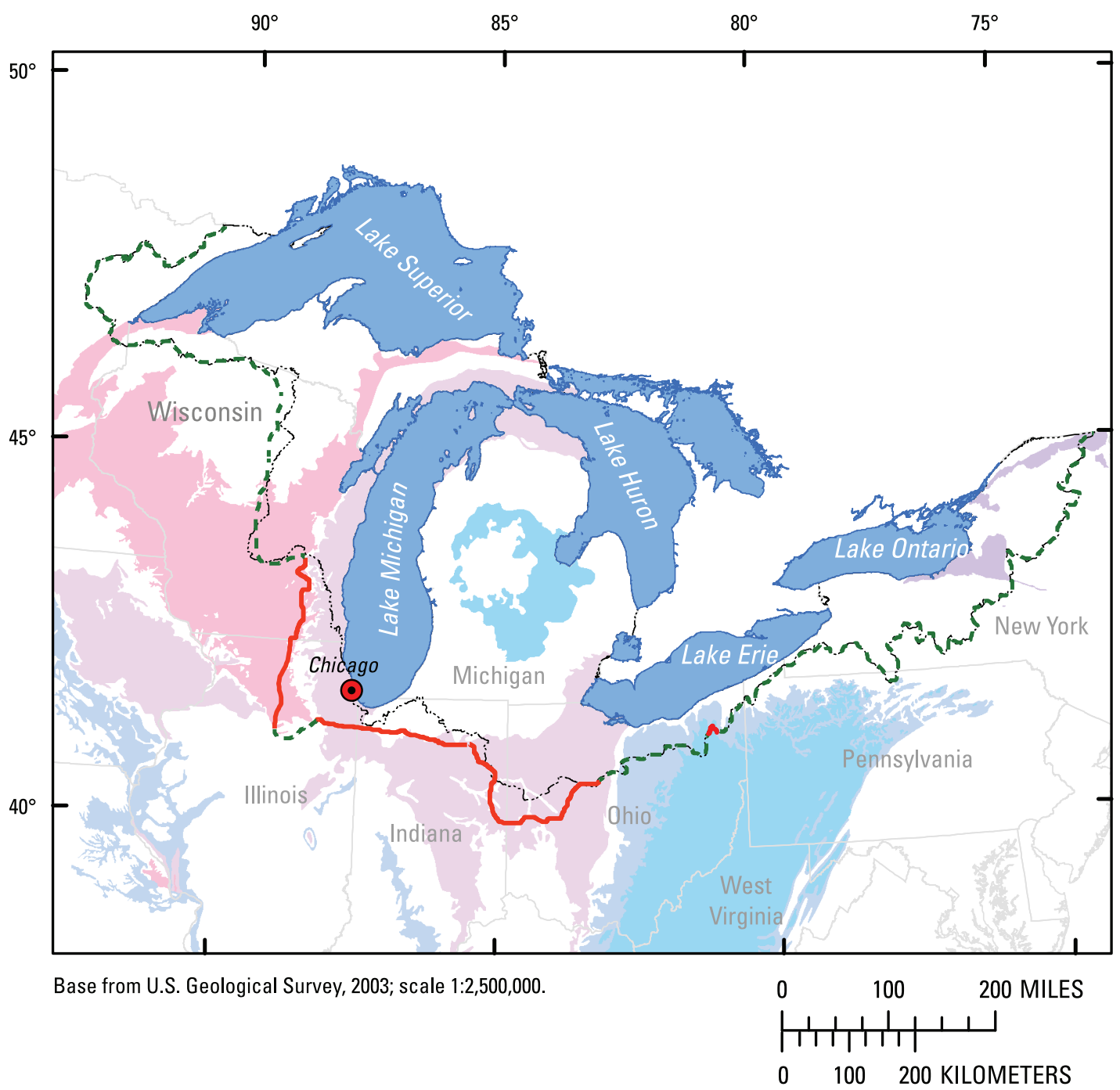

\section{EXPLANATION}

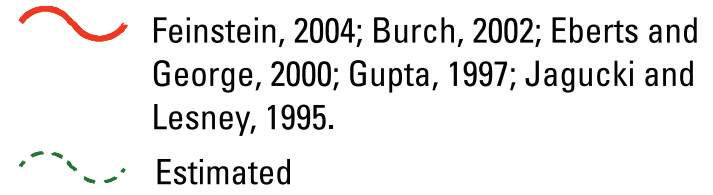

Great Lakes Basin surface-water divide

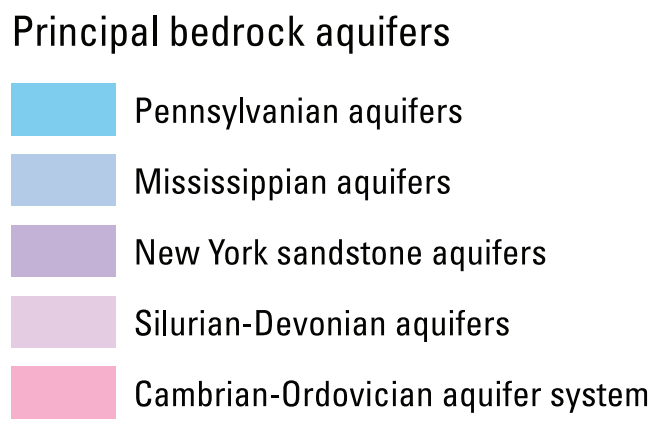

Figure 10. Composite ground-water divide in the principal consolidated-rock aquifers in the Great Lakes region, United States (lines dashed where approximate). 
depicted to mimic the surface-water divide (fig. 10). Gupta and Bair (1997) indicated that the positions of the divides in the Cambrian-Ordovician aquifer system are influenced by major structural features in the aquifer system, such as faults. Studies of the Mississippian and Pennsylvanian aquifers in northeastern Ohio (Eberts and others, 1990; Eberts, 1991; Jagucki and Lesney, 1995) indicate that the dip of the beds plays a minor role in ground-water flow. These studies helped derive the information necessary to extrapolate the regional ground-water divide for these aquifers in areas with very little documented data (fig. 10).

The composite ground-water divide is very close to the surface-water divide, except in areas where pumping or other anthropogenic and (or) natural factors affect the position of the divide, such as in northeastern Illinois and southeastern Wisconsin (Box 1; fig. 10). In northeastern Indiana and northwestern Ohio, the composite regional ground-water divide is inconsistent with the regional surface-water divide. A lack of major pumping influencing the ground-water divide in these areas indicates that other anthropogenic factors such as widespread tile drainage or a natural factor such as isostatic rebound might have affected the position of the ground-water divide.

\section{Summary and Conclusions}

A compilation is presented of positions of regional ground-water divides for the five principal aquifers corresponding to the Great Lakes Basin. These divides are based on previously published reports on ground-water flow, potentiometric-surface maps, or delineated ground-water flow divides. These reports varied in the amount of data used to interpret the potentiometric surfaces or ground-water flow divides; some reports are based entirely on computer simulations or modeling results. The variability in the positions of the regional ground-water divides is entirely dependent upon the sources of data.

Past studies most often focused on areas where groundwater use from an aquifer system is concentrated. If the rocks that compose the principal aquifers are near land surface, they are more likely to be used (and studied), and it is more likely that a potentiometric surface or ground-water divide has been delineated. As an aquifer system dips into a structural basin, it is usually covered by another aquifer, and the upper aquifer is more likely to be tapped by users. Water quality in the deeper aquifer system also is more likely to be considered undesirable by users, owing to the presence of higher concentrations of dissolved minerals. This compilation also shows that positions of regional ground-water divides are not known for large parts of some of these regional aquifer systems.

Generally, the central part of the Great Lakes Basin is lacking information on regional ground-water divides, and the western part has the most information. Other areas where data to delineate regional ground-water divides are minimal or absent are in the eastern part of the basin (Pennsylvania to New York) and in parts of western and central Ohio.

Results from the Cambrian-Ordovician aquifer system, primarily in eastern Illinois and Wisconsin, show that the recently mapped regional ground-water divides have been altered from predevelopment positions by pumping, primarily in eastern Illinois and Wisconsin. Measured potentiometric surfaces show that the regional ground-water divide in the Silurian-Devonian aquifers generally follows topographic divides but in some places is substantially different from the regional surface-water divide. Only a few local-scale (county) studies could be used for delineation of the regional groundwater divide in the Mississippian and Pennsylvanian aquifers, primarily because the aquifers are not extensively used over a large area and because of the relatively small area where these aquifers crop out near the Great Lakes Basin surfacewater divide. The limited studies do show that the positions of the ground-water divides tend to be similar to those of the surface-water divides for the Mississippian and Pennsylvanian aquifers. The position of the regional ground-water divide for the surficial aquifer system generally is very similar to that of the regional surface-water divide, as indicated by several localscale to regional-scale studies. The composite ground-water divide, then, was estimated to mimic the surface-water divide in most areas except where human activity and natural factors affect ground-water flow.

Many factors can affect the position of local and regional ground-water flow divides. Pumping of ground water causes changes in ground-water flow patterns; as a result, if pumping is near enough to ground-water divides, the position of the divides will shift. Likewise, changes in recharge to the groundwater system can also affect ground-water flow patterns and the position of ground-water flow divides. Very long-term changes to ground-water flow and divides can also result from topographic changes due to crustal rebound. These factors can influence the position of the ground-water divide; discrete measurements of ground-water levels and mapping of the potentiometric surface are needed to determine ground-water flow directions and changes in ground-water flow.

\section{Acknowledgments}

The authors thank the staff of the Illinois State Water Survey for searching the agency's publications and contributing relevant references for this study. For similar efforts, the authors thank the staff of USGS Water Science Centers in Ohio, Michigan, Indiana, Illinois, Wisconsin, Minnesota, Pennsylvania, and New York. 


\section{References Cited}

Alley, W.M., Healy, R.W., LaBaugh, J.W., and Reilly, T.E., 2002, Flow and storage in groundwater systems: Science, v. 296, p. 1985-1990.

Bugliosi, E.F., 1999, The Midwestern Basins and Arches regional aquifer system in parts of Indiana, Ohio, Michigan, and Illinois-Summary: U.S. Geological Survey Professional Paper 1423-A, 46 p.

Burch, S.L., 1991, The new Chicago model-A reassessment of the impacts of Lake Michigan allocations on the CambrianOrdovician aquifer system in northeastern Illinois: Illinois State Water Survey Research Report 119, 52 p.

Burch, S.L., 2002, A comparison of potentiometric surfaces for the Cambrian-Ordovician aquifers of northeastern Illinois, 1995 and 2000: Illinois State Water Survey Data/Case Study 2002-02, 63 p.

Clark, R.H., and Persoage, N.P., 1970, Some implications of crustal movement in engineering planning: Canadian Journal of Earth Sciences, v. 7, p. 628-633.

Cohee, G.V., 1962, Tectonic map of the United States, exclusive of Alaska and Hawaii, by the United States Geological Survey and American Association of Petroleum Geologists: U.S. Geological Survey, scale 1:2,500,000.

Cotter, R.D., Hutchinson, R.D., Skinner, E.L., and Wentz, D.A., 1969, Water resources of Wisconsin Rock-Fox River Basin: U.S. Geological Survey Hydrologic Investigations Atlas HA- 360, 4 sheets, scale 1:1,000,000.

Delin, G.N., and Woodward, D.G., 1980, Hydrogeologic setting and the potentiometric surfaces of regional aquifers in the Hollandale Embayment, southeastern Minnesota, 1970-1980: U.S. Geological Survey Water-Supply Paper 2219, 56 p.

Devaul, R.W., and Green, J.H., 1971, Water resources of Wisconsin-Central Wisconsin River Basin: U.S. Geological Survey Hydrologic Investigations Atlas HA-367, 4 sheets, scale $1: 1,000,000$.

Eberts, S.M., 1991, Geohydrology and water quality in northern Portage County, Ohio, in relation to deep-well brine injection: U.S. Geological Survey Water-Resources Investigations Report 90-4158, 63 p.

Eberts, S.M., 1999, Water levels and ground-water discharge, regional aquifer system of the Midwestern Basins and Arches Region, in parts of Indiana, Ohio, Illinois, and Michigan: U.S Geological Survey Hydrologic Investigations Atlas HA-725, 3 sheets, scale 1:2,000,000.
Eberts, S.M., Bair, E.S., and de Roche, J.T., 1990, Geohydrology, ground-water quality, and simulated ground-water flow, Geauga County, Ohio: U.S. Geological Survey WaterResources Investigations Report 90-4026, 117 p.

Eberts, S.M., and George, L.L., 2000, Regional ground-water flow and geochemistry in the Midwestern Basin and Arches aquifer system in parts of Indiana, Ohio, Michigan, and Illinois: U.S. Geological Survey Professional Paper 1423-C, $103 \mathrm{p}$.

Feinstein, D.T., Hart, D.J., Eaton, T.T., Krohelski, J.T., and Bradbury, K.R., 2004, Simulation of regional groundwater flow in southeastern Wisconsin: Wisconsin Geological and Natural History Survey Open-File Report 2004-01, 1 CD-ROM.

Fenneman, N.M., and Johnson, D.W., 1946, Physical divisions of the United States: U.S. Geological Survey, 1 sheet, scale $1: 7,000,000$.

Government of Canada and U.S. Environmental Protection Agency, 1995, The Great Lakes-An environmental atlas and resource book: EPA 905-B-95-001, 46 p.

Grannemann, N.G, Hunt, R.J., Nicholas, J.R., Reilly, T.E., and Winter, T.C., 2000, The importance of ground water in the Great Lakes Region: U.S. Geological Survey Water-Resources Investigations Report 00-4008, 13 p.

Grannemann, N.G., and Reeves, H.W., 2005, Great Lakes Basin water availability and use-A study of the National Assessment of Water Availability and Use Program: U.S. Geological Survey Fact Sheet 2005-3113, 4 p.

Great Lakes Commission, 2005, Annual report of the Great Lakes regional water use database repository: Ann Arbor, Mich., 64 p., accessed March 6, 2006, at http://www.glc.org/ wateruse/database

Greeman, T.K., 1991, Areal differences between surface-water and ground-water drainage basins in Indiana [abs.], in 36th Midwest Groundwater Conference-Program with Abstracts: Indianapolis, p. 106-107.

Gupta, Neeraj, and Bair E.S.,1997, Variable-density flow in the mid-continent Basins and Arches region of the United States: Water Resources Research, v. 33, n. 8, p. 1785-1802.

Helgesen, J.O., Lindholm, G.F., Broussard, W.L., and Ericson, D.W., 1973, Water resources of the Kettle River watershed, east-central Minnesota: U.S. Geological Survey Hydrologic Investigations Atlas HA-437, 4 sheets, scale 1:250,000.

Helgesen, J.O., Lindholm, G.F., and Ericson, D.W., 1976, Water resources of the Little Fork River Watershed, northeastern Minnesota: U.S. Geological Survey Hydrologic Investigations Atlas HA-551, 2 sheets, scale 1:250,000. 
Indiana Department of Natural Resources, 1987, Water resource availability in the St. Joseph River Basin: Water Resources Assessment 87-1, 139 p., available at http://www.in.gov/dnr/ water/publications/publicat/Basin101.htm

Indiana Department of Natural Resources, 1990, Water resource availability in the Kankakee River Basin, Indiana: Water Resources Assessment 90-3, 247 p., available at http://www. in.gov/dnr/water/publications/publicat/Basin103.htm

Indiana Department of Natural Resources, 1994, Water resource availability in the Lake Michigan Region, Indiana: Water Resources Assessment 94-4, 257 p., available at http://www. in.gov/dnr/water/publications/publicat/Basin104.htm

Jagucki, M.L., and Lesney, L.L., 1995, Ground-water levels and directions of flow in Geauga County, Ohio, September 1994, and changes in ground-water levels, 1986-94: U.S. Geological Survey Water-Resources Investigations Report 95-4194, 28 p.

Kammerer, P.A., 1995, Ground-water flow and quality in Wisconsin's shallow aquifer system: U.S. Geological Survey Water-Resources Investigations Report 90-4171, 42 p.

Kappel, W.M., Miller, T.S., and Hetcher, K.K., 2001, Hydrogeology of the Tully Lakes area in southern Onondaga and northern Cortland Counties, New York: U.S. Geological Survey Water -Resources Investigations Report 01-4166, 16 p.

Kay, R.T., Duwelius, R.F., Brown, T.A., Micke, F.A., and WittSmith, C.A., 1996, Geohydrology, water levels and directions of flow, and occurrence of light-nonaqueous-phase liquids on ground water in northwestern Indiana and the Lake Calumet area of northeastern Illinois: U.S. Geological Survey WaterResources Investigations Report 95-4253, 84 p.

Lindholm, G.F., Ericson, D.W., Broussard, W.L., and Hult, M.F., 1979, Water resources of the St. Louis River watershed, northeastern Minnesota: U.S. Geological Survey Hydrologic Investigations Atlas HA-586, 4 sheets.

Lloyd, O.B., Jr., and Lyke, W.L., 1995, Ground water atlas of the United States-segment 10, Illinois, Indiana, Kentucky, Ohio, and Tennessee: U.S. Geological Survey Hydrologic Investigations Atlas HA-730-K, accessed July 13, 2005, at http://pubs. er.usgs.gov/pubs/ha/ha730K

Mandle, R.J., and Kontis, A.L., 1992, Simulation of regional ground-water flow in the Cambrian-Ordovician Aquifer System in the northern Midwest, United States: U.S. Geological Survey Professional Paper 1405-C, 97 p.

Miller, J.A., 1999, Ground water atlas of the United StatesIntroduction and National summary: U.S. Geological Survey Hydrologic Investigations Atlas HA-730-A, 36 p.

Myette, C.F., 1986, Hydrogeology of sand-plain aquifers in Carlton, Kanabec, and Pine Counties, east-central Minnesota: U.S. Geological Survey Water-Resources Investigations Report 85-4334, 66 p.
Neff, B.P., and Nicholas, J.R., 2005, Uncertainty in the Great Lakes water balance: U.S. Geological Survey Scientific Investigations Report 2004-5100, 42 p.

Neff, B.P., Piggott A.R., and Sheets, R.A., 2006, Estimation of shallow ground-water recharge in the Great Lakes Basin: U.S. Geological Survey Scientific Investigations Report 20055284, 22 p.

Oakes, E.L, and Bidwell, L.E., 1968, Water resources of the Mississippi headwaters watershed, north-central Minnesota: U.S. Geological Survey Hydrologic Investigations Atlas HA-278, 4 sheets, scale 1:250,000.

Oakes, E.A., and Cotter, R.D., 1975, Water resources of Wisconsin Upper Wisconsin River Basin: U.S. Geological Survey Hydrologic Investigations Atlas HA-536, 3 sheets, scale $1: 1,000,000$.

Oakes, E.L., and Hamilton, L.J., 1973, Water resources of Wisconsin-Menominee-Oconto-Peshtigo River Basin: U.S. Geological Survey Hydrologic Investigations Atlas HA-470, 4 sheets, scale 1:1,000,000.

Olcott, P.G., 1968, Water resources of Wisconsin Fox-Wolf River Basin: U.S. Geological Survey Hydrologic Investigations Atlas HA-321, 4 sheets, scale 1:1,000,000.

Olcott, 1992, Ground water atlas of the United Statessegment 9, Iowa, Michigan, Minnesota, and Wisconsin: U.S. Geological Survey Hydrologic Investigations Atlas 730-J, accessed July 13, 2005 at http://pubs.er..usgs.gov/pubs/ha/ ha730J

Olcott, P.G., Ericson, D.W., Felsheim, P.E., and Broussard, W.L., 1978, Water resources of the Lake Superior watershed, northeastern Minnesota: U.S. Geological Survey Hydrologic Investigations Atlas HA-582, 4 sheets, scale 1:250,000.

Pettijohn, R.A., and Davis, L.G., 1973, Water resources of the Maumee River Basin, northeastern Indiana: U.S. Geological Survey Hydrologic Investigations Atlas HA-493, 3 sheets, scale $1 ; 250,000$.

Randall, A.D., Snavely, D.S., Holecek, T.J., and Waller, R.M., 1988, Alternative sources of large seasonal ground-water supplies in the headwaters of the Susquehanna River Basin, New York: U.S. Geological Survey Water-Resources Investigations Report 85-4127, 121 p.

Russell, R.R., 1963, Ground-water levels in Illinois through 1961: Illinois State Water Survey Report of Investigation 45, $51 \mathrm{p}$.

Sasman, R.T., Ludwigs, R.S., Benson, C.R., and Kirk, J.R., 1960, Water-level decline and pumpage during 1959 in deep wells in the Chicago region, Illinois: Illinois State Water Survey Circular 79, $37 \mathrm{p}$. 
Sasman, R.T., Ludwigs, R.S., Benson, C.R., and Kirk, J.R., 1986, Water-level decline and pumpage in the Cambrian and Ordovician aquifers in the Chicago region, 1980-1985: Illinois State Water Survey Circular 166, 47 p.

Sasman, R.T., Benson, C.R., Mende, J.S., Gangler, N.F., and Colvin, V.M., 1977, Water-level decline and pumpage in deep wells in the Chicago region, 1971-1975: Illinois State Water Survey Circular 125, $35 \mathrm{p}$.

Schruben, P.G., Arndt, R.E., and Bawiec, W.J., 2002, Geology of the conterminous United States at 1:2,500,000 scaleA digital representation of the 1974 P.B. King and H.M. Beikman map: Accessed July 6, 2005, at http://pubs.usgs. gov/dds/dds $11 / \mathrm{kb} . \mathrm{html}$

Sheets, R.A., Dumouchelle, D.H., and Feinstein, D.T., 2005, Ground-water modeling of pumping effects near regional ground-water divides and river/aquifer systems-Results and implications of numerical experiments: U.S. Geological Survey Scientific Investigations Report 2005-5141, 34 p.

Shum, C., Kuo, C., and Mitrovica, J.X., 2002, Glacial isostatic adjustment in the Great Lakes Region inferred by tide gauges and satellite altimetry [abs.]: American Geophysical Union, Spring meeting 2002, accessed March 6, 2006, at http://www. agu.org/meetings/sm02top.html

Skinner, E.L., and Borman, R.G., 1973, Water resources of Wisconsin—Lake Michigan Basin: U.S. Geological Survey Hydrologic Investigations Atlas HA-432, 4 sheets, scale $1: 1,000,000$.

Solley, W.B., Pierce, R.R., and Perlman, H.A., 1998, Estimated use of water in the United States in 1995: U.S. Geological Survey Circular 1200, 71 p.

Southeastern Wisconsin Regional Planning Commission, 2002, Groundwater resources of southeastern Wisconsin: Waukesha, Wis., Technical Report 37, 203 p.

Strobel, M.L., and Bugliosi, E.F., 1991, Areal extent, hydrogeologic characteristics, and possible origins of the carbonate rock Newburg zone (Middle-Upper Silurian) in Ohio: Ohio Journal of Science, v. 91, no. 5, p. 209-215.

Tate, C.H., Davis, L.G., Johnson, L.E., and Pettijohn, R.A., 1973, Water resources of the Upper Wabash River Basin, northeastern Indiana: U.S. Geological Survey Hydrologic Investigations Atlas HA-433, 3 sheets, scale 1:250,000.

Trescott, P.C., Pinder, G.F., and Larson, S.P., 1976, Finite-difference model for aquifer simulation in two dimensions with results of numerical experiments: U.S. Geological Survey Techniques of Water-Resources Investigations, book 7, chap. $\mathrm{C} 1,116 \mathrm{p}$.

U.S. Geological Survey, 2002, Concepts for national assessment of water availability and use-Report to Congress: U.S. Geological Survey Circular 1223, 34 p.
U.S. Geological Survey, 2003, Principal aquifers of the 48 conterminous United States, Hawaii, Puerto Rico, and the U.S. Virgin Islands, scale 1:2,500,000: Accessed July 19, 2005, at http://www.nationalatlas.gov/mld/aquifrp.html

U.S. Geological Survey, 2005a, Ground water in the Great Lakes Basin-The case of southeastern Wisconsin: Accessed July 19, 2005, at http://wi.water.usgs.gov/glpf/

U.S. Geological Survey, 2005b, National Assessment of Water Availability and Use: Accessed July 11, 2005, at http://www. usgs.gov/budget/2006/wateravail021405.pdf

Visocky, A.P., 1997, Water-level trends and pumpage in deep bedrock aquifers in the Chicago region, 1991-1995: Illinois State Water Survey Circular 182, 45 p.

Walton, W.C., 1965, Ground-water recharge and runoff in Illinois: Illinois State Water Survey Report of Investigations 48, $55 \mathrm{p}$.

Weidman, S., and Schultz, A.R., 1915, The underground and surface water supplies of Wisconsin: Wisconsin Geological and Natural History Survey Bulletin 35, pl. 1.

Young, H.L., 1992, Summary of ground-water hydrology of the Cambrian-Ordovician aquifer system in the northern Midwest: U.S. Geological Survey Professional Paper 1405-A, 55 p.

Young, H.L., and Hindall, S.M., 1972a, Water resources of Wisconsin St. Croix River Basin: U.S. Geological Survey Hydrologic Investigations Atlas HA-451, 4 sheets, scale $1: 1,000,000$.

Young, H.L., and Hindall, S.M., 1972b, Water resources of Wisconsin Chippewa River Basin: U.S. Geological Survey Hydrologic Investigations Atlas HA-386, 4 sheets, scale $1: 1,000,000$.

Young, H.L., MacKenzie, A.J., and Mandle, R.J., 1989, Simulation of ground-water flow in the Cambrian-Ordovician aquifer system in the Chicago-Milwaukee area of the Northern Midwest-A summary, in Swain, L.A., and Johnson, A.I., eds., Regional aquifer systems of the United States, aquifers of the Midwestern Area: American Water Resources Association Monograph Series, no. 13, p. 39-72.

Zucker, L.A. and Brown, L.C., eds., 1998, Agricultural drainage-Water quality impacts and subsurface drainage studies in the Midwest: Columbus, Ohio, Ohio State University Extension Bulletin 871, 40 p. 


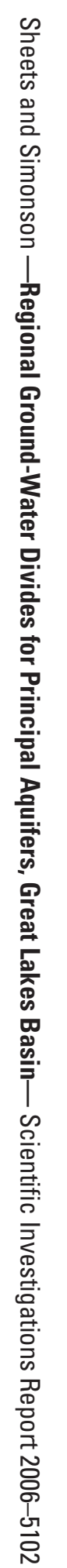

8 Printed on recycled paper 